\title{
Bi-fated tendon-to-bone attachment cells are regulated by shared enhancers and KLF transcription factors
}

\section{Shiri Kult ${ }^{1}$, Tsviya Olender ${ }^{1}$, Marco Osterwalder ${ }^{2,3}$, Svetalana Markman ${ }^{1}$, Dena Leshkowitz ${ }^{4}$, Sharon Krief ${ }^{1}$, Ronnie Blecher-Gonen ${ }^{5}$, Shani Ben-Moshe ${ }^{6}$, Lydia Farack ${ }^{6}$, Hadas Keren-Shaul ${ }^{4}$, Tomer-Meir Salame ${ }^{4}$, Terence D Capellini ${ }^{7}$, Shalev Itzkovitz ${ }^{6}$, Ido Amit ${ }^{5}$, Axel Visel ${ }^{2,8,9}$, Elazar Zelzer ${ }^{1 *}$}

1Department of Molecular Genetics, Weizmann Institute of Science, Rehovot, Israel; ${ }^{2}$ Environmental Genomics and Systems Biology Division, Lawrence Berkeley National, Berkeley, United States; ${ }^{3}$ Department for BioMedical Research (DBMR), University of Bern, Bern, Switzerland; ${ }^{4}$ Life Sciences Core Facilities, Weizmann Institute of Science, Rehovot, Israel; ${ }^{5}$ Department of Immunology, Weizmann Institute of Science, Rehovot, Israel; ' Department of Molecular Cell Biology, Weizmann Institute of Science, Rehovot, Israel; ${ }^{7}$ Department of Human Evolutionary Biology, Harvard University, Department of Human Evolutionary Biology, United States; Broad Institute of Harvard and MIT, Cambridge, United States; ${ }^{8}$ U.S. Department of Energy Joint Genome Institute, Lawrence Berkeley National Laboratory, Berkeley, United States; ${ }^{9}$ School of Natural Sciences, University of California, Merced, Merced, United States
*For correspondence: eli.zelzer@weizmann.ac.il

Competing interests: The authors declare that no competing interests exist.

Funding: See page 20

Received: 21 January 2020 Accepted: 30 November 2020 Published: 15 January 2021

Reviewing editor: Shahragim Tajbakhsh, Institut Pasteur, France

(c) Copyright Kult et al. This article is distributed under the terms of the Creative Commons Attribution License, which permits unrestricted use and redistribution provided that the original author and source are credited.

\begin{abstract}
The mechanical challenge of attaching elastic tendons to stiff bones is solved by the formation of a unique transitional tissue. Here, we show that murine tendon-to-bone attachment cells are bi-fated, activating a mixture of chondrocyte and tenocyte transcriptomes, under regulation of shared regulatory elements and Krüppel-like factors (KLFs) transcription factors. Highthroughput bulk and single-cell RNA sequencing of humeral attachment cells revealed expression of hundreds of chondrogenic and tenogenic genes, which was validated by in situ hybridization and single-molecule ISH. ATAC sequencing showed that attachment cells share accessible intergenic chromatin areas with either tenocytes or chondrocytes. Epigenomic analysis revealed enhancer signatures for most of these regions. Transgenic mouse enhancer reporter assays verified the shared activity of some of these enhancers. Finally, integrative chromatin and motif analyses and transcriptomic data implicated KLFs as regulators of attachment cells. Indeed, blocking expression of both KIf2 and Klf4 in developing limb mesenchyme impaired their differentiation.
\end{abstract}

\section{Introduction}

The function of the musculoskeletal system relies on the proper assemblage of its components, namely skeletal tissues (bone, cartilage, and joints), muscles, and tendons. However, the attachment of tissues composed of materials with large differences in their mechanical properties is highly challenging. In the musculoskeleton, elastic tendons, which have a Young's modulus (a measure of stiffness) in the order of 200 megapascal, are attached to the much harder bone, with a modulus in the order of 20 gigapascal. This disparity makes the connection between these two tissues a mechanical weak point, which is subject to higher incidence of tearing by both external and internal forces acting on the musculoskeleton during movement. The evolutionary solution to this problem is the 
enthesis, a transitional tissue that displays a gradual shift in cellular and extracellular properties from the tendon side through to the bone side (Genin et al., 2009; Liu et al., 2011; Liu et al., 2012a; Lu and Thomopoulos, 2013; Thomopoulos et al., 2003). Yet, despite its importance, the formation of this cellular gradient as well as the underlying molecular mechanism remain largely unknown.

In recent years, the initial events that lead to the formation of the embryonic attachment unit $(A U)$, which serves as the primordium of the enthesis, have started to be investigated. These studies identified the progenitors of the $A U$ and showed that they express both the chondrogenic and tenogenic transcription factors Sox9 and scleraxis (Scx), respectively (Blitz et al., 2013; Sugimoto et al., 2013). The patterning of the $\mathrm{Sox}^{+} / \mathrm{Scx}{ }^{+}$progenitors along the skeleton is regulated by a genetic program that includes several transcription factors (Eyal et al., 2019). Next, Sox $9^{+} / \mathrm{Scx}{ }^{+}$progenitors differentiate to chondrocytes, which form a bone eminence on one side, or to tenocytes, which form the tendon on the other side, whereas the cells in between differentiate into $\mathrm{Gli}^{+}$cells that eventually will form the enthesis (Felsenthal et alı, 2018; Schwartz et al., 2017; Schwartz et al., 2015).

Both molecular and mechanical signals regulate the AU. TGF $\beta$ signaling regulates the specification of $A U$ progenitors, whereas BMP and FGF signaling as well as mechanical signals determine their fate and differentiation (Blitz et al., 2013; Blitz et al., 2009; Roberts et al., 2019). Postnatal enthesis cells have been termed fibrocartilage cells based on their histological appearance, because they display morphological features that are shared with tenocytes and chondrocytes (Thomopoulos et al., 2010). In recent years, several studies have identified some of the genes that these cells express, including collagens type I, II, and X; Indian hedgehog (Ihh); parathyroid hormone-related peptide (Pth/h); patched 1 (Ptc1); runt-related transcription factor 2 (Runx2); tenascin C (Tnc); and biglycan (Bgn) (Liu et al., 2012b; Liu et al., 2013; Liu et al., 2018; Thomopoulos et al., 2010). Interestingly, these genes are also expressed by cells in the neighboring tissues, namely by chondrocytes or tenocytes. However, despite these advances, a comprehensive molecular signature of this tissue and the mechanism that enables its formation are still missing.

In this work, we aimed to decipher the identity of the fibrocartilage cells that form the attachment tissue between tendon and bone. Bulk and single-cell transcriptomic analyses of the attachment cells, which were validated by in situ hybridization (ISH) and single-molecule fluorescent ISH (smFISH), showed that these cells express a mix of the transcriptomes of chondrocytes and tenocytes. Chromatin analysis further verified the transcriptomic results and provided a mechanistic explanation for the bi-fated behavior of attachment cells, which share enhancers with their neighboring tenocytes or chondrocytes. Finally, we identify the transcription factors KLF2 and KLF4 as regulators of attachment cell differentiation. Overall, we provide the transcriptional as well as the epigenetic mechanism that allows attachment cells to activate a combination of cartilage and tendon transcriptomes and, thereby, the formation of the unique transitional tissue.

\section{Results}

\section{Attachment cell transcriptome is a mix of chondrocyte and tenocyte transcriptomes}

To date, the transcriptome of attachment cells has not been characterized thoroughly. We therefore analyzed the transcriptome of embryonic day (E) 14.5 attachment cells from the prominent deltoid tuberosity and greater tuberosity of the humerus. With the goal to isolate these cells specifically, we generated a compound mouse by crossing three mouse lines, namely Col2a1-Cre, R26R-tdTomato, and Scx-GFP (see Materials and methods) (Blitz et al., 2013; Sugimoto et al., 2013). Thus, the fluorescent reporter tdTomato labeled Col2a1-expressing chondrocytes, whereas GFP fluorescently labeled Scx-expressing tenocytes. Unexpectedly, the two reporters failed to label the attachment cells that were located in between these two populations. This failure might be due to a missing regulatory element in one of the constructs that were used to produce each transgenic reporter. Nevertheless, the borders between tendon and attachment cells and between cartilage and attachment cells were clearly demarcated (Figure 1A, Figure 1-figure supplement 1A,B). We therefore used laser capture microdissection (LCM) to subdivide the attachment site into three cellular compartments, namely attachment cells, adjacent tenocytes, and adjacent chondrocytes. As controls, samples were also taken from two more compartments, remote tenocytes and remote chondrocytes. Initial analysis of the different transcriptomes using principal components analysis (PCA) showed that 


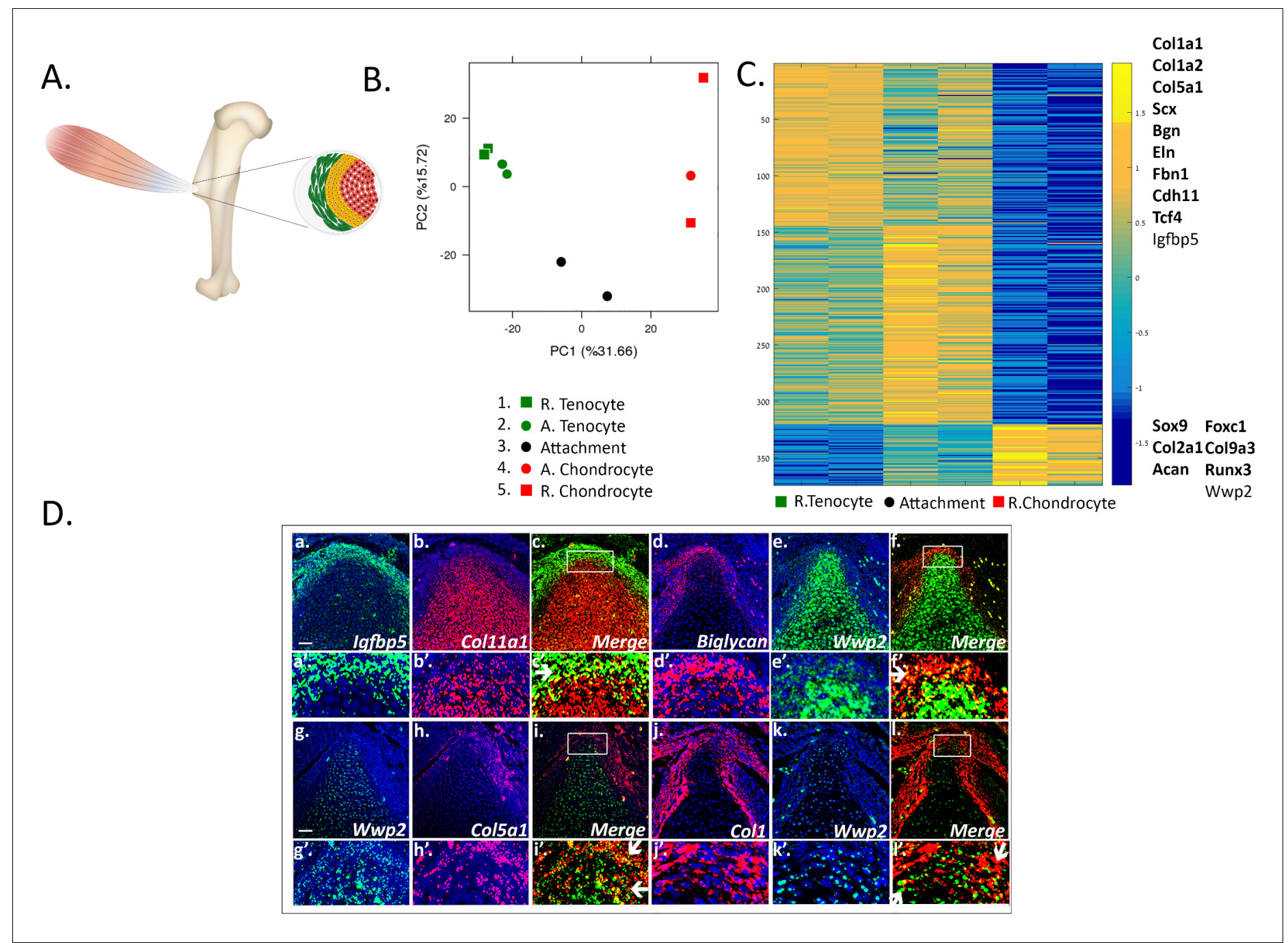

Figure 1. Transcriptomic analysis of tendon-to-bone attachment site domains at E14.5. (A) A scheme of tendon-to-bone attachment site of the murine deltoid tuberosity. (B) Principal component analysis (PCA) of bulk MARS-seq data from E14.5 attachment site samples. The $x$-axis (PC1) shows the highest variance among the samples. Interestingly, the samples are arranged according to their anatomical locations. ' $R$ ' (samples 1 and 5) stands for remote and ' $A$ ' (samples 2 and 4) is for adjacent. The $y$-axis (PC2) shows that tenocytes and chondrocytes are closer to one another, while attachment cells (black circle) were found to be remote from both of them, that is with higher variance, suggesting a unique gene expression profile. (C) Heatmap of gene expression profiles at E14.5 shows 374 selected genes that exhibited differential expression between tenocytes and chondrocytes and were also expressed by attachment cells. Color bar (-1.5-0-1.5) represents the log-normalized counts standardized per gene, as yellow is higher than the mean (0) and blue is lower than the mean. Attachment cells display a gradient of gene expression profiles, reflecting their function as a transitional tissue. The upper cluster contains genes highly expressed in tenocytes (e.g. Co1a1, Col1a2, Col5a1, Scx, Bgn), whereas the lower cluster contains genes highly expressed in chondrocytes (e.g. Sox9, Col2a1, Acan). Top list on the right contains genes found to be expressed in attachment cells and in tenocytes, whereas bottom list contains genes expressed in attachment cells and chondrocytes; genes in bold type are known tenocyte or chondrocyte markers. D (a-I). Double-fluorescent ISH for mRNA of tendon (Igfbp5, biglycan, Col5a1, Col1a1) and cartilage (Col11a1 or Wwp2) genes shows that attachment cells (in yellow, shown by arrows) exhibit an in vivo gene expression profile that combines tendon and cartilage genetic programs. a-I: X20 magnification, scale bar: $50 \mu \mathrm{m}$; $\mathrm{a}^{\prime}-\mathrm{I}^{\prime}$ : magnification of upper panels.

The online version of this article includes the following figure supplement(s) for figure 1:

Figure supplement 1. Analysis of the embryonic tendon-to-bone attachment site in a triple-transgenic mouse line.

Figure supplement 2. Transcriptomic analysis of tendon-to-bone attachment site domains at E14.5.

Figure supplement 3. Upregulated gene expression in attachment cells.

Figure supplement 4. Validation of RNA sequencing results by fluorescent in situ hybridization analysis. 
the transcriptomes of tenocytes and chondrocytes were clearly separated, whereas attachment cells were located between the two cell types, recapitulating their anatomical positions. This suggests that the attachment cell transcriptome is shared with both chondrocytes and tenocytes (Figure 1B, PC1 31.66\%).

To further support our initial observation that the transcriptome of the attachment cells is a mixture of chondrocyte and tenocyte transcriptomes, we clustered the statistically significant differentially expressed genes between all samples into five clusters, using CLICK (Figure 1-figure supplement 2 and see Materials and methods). Out of 865 identified genes, 735 genes were found in two clusters. The first cluster contained mainly known tenogenic genes and the second contained chondrogenic genes. From these two clusters, 374 genes, 320 of them tenogenic and 54 chondrogenic, were also found to be expressed by attachment cells. They included major regulators and marker genes of the two tissues, such as Sox9, Col2a1, and Acan for chondrocytes and Col1a1, Col1a2, Scx, and Col5a1 for tenocytes (Figure 1C).

The third cluster comprised 54 genes that were found to be upregulated in cartilage adjacent to attachment cells alone (Figure 1-figure supplement 2). Interestingly, our analysis identified 24 and 23 genes that were found to be down- or upregulated in attachment cells, shown by the fourth and fifth clusters, respectively (Figure 1-figure supplement 2). The genes that were found to be uniquely upregulated in attachment cells included transcription factors, such as the Krüppel-like factors (KLFs), Lmo1, and Gli1, which could act as regulators of the genetic program of attachment cells. In addition, this set included differentiation markers such as Thy1, regulators of bone for example Acp5 and Alpl, protein kinases such as Mapk12 and Mast2, and signaling molecules such as Nod, Traip, Aplnr and others (Figure 1-figure supplement 3A,B). GO analysis of these genes yielded terms relating to regulation of cytokine and IL-12 production, as well as response to laminar fluid shear stress (Figure 1-figure supplement $3 \mathrm{C}$ ). These results clearly show that the transcriptome of the attachment cells includes a mixture of tenocyte and chondrocyte genes, many of which are involved in ECM organization and developmental processes, in addition to a unique subgroup of genes that are upregulated in these cells. To determine the relative proximity of attachment cells to the other two cell types, we performed hierarchical clustering on the 865 differentially expressed genes. Results showed that these cells are closer to tenocytes (Supplementary file 1).

To validate our transcriptome analysis, we performed single- and double-fluorescent in situ hybridization (FISH) using marker genes for tenocytes and chondrocytes that were selected from the transcriptomic results, namely lgfbp5, biglycan (Bgn), Col5a1, and Col1a1 for tenocytes and Col11a1 and Wwp2 for chondrocytes. As seen in Figure 1D and Figure 1-figure supplement 4, in agreement with the transcriptome analysis, the selected markers were co-expressed by the attachment cells.

\section{Single-cell RNA-seq reveals the bi-fated nature of attachment cells}

Finding that the bulk transcriptome of attachment cells represents a mixture of tenocyte and chondrocyte genes led us to examine if this phenotype also exists at a single-cell resolution by performing scRNA-seq. To isolate E13.5 $\mathrm{Sox}^{+} / \mathrm{Scx}^{+}$attachment progenitors, we generated a compound mouse line harboring Sox9-CreER, tdTomato and Scx-GFP transgenes (Figure 1-figure supplement $1 C-E)$. Then, FACS-sorted attachment progenitors from the proximal side of the forelimb underwent single-cell 10x Genomics RNA sequencing (Figure 2A, B and see Materials and methods). Sequenced progenitors were then filtered, normalized, and clustered (Seurat 3.1.5).

Results showed five transcriptionally distinct subpopulations (Figure 2A). Examination of the top10 differentially expressed genes across clusters revealed that they were subdivided to three main categories. Clusters 1 and 3 were highly rich with chondrogenic genes (Sox9, Sox5, Col2a1, Wwp2), whereas clusters 2 and 4 were highly rich with tenogenic genes (Scx, Hic1, Ptn, lgfbp5). By contrast, the identity of cluster 0 was less specified, as it was highly rich with genes such as Col1a1, Alpl, Spp1, and Runx2 in addition to Bicc1, Maf, and Mef2c (Figure 2-figure supplement 1).

To study the bi-fated nature of attachment cells, we analyzed the relative expression of tenogenic (Scx, Col1a2, biglycan) and chondrogenic (Sox9, Col2a1, Wwp2) marker genes in each subpopulation. As seen in Figure 2B, all five clusters contained both chondrogenic and tenogenic marker genes. However, while tenogenic genes were relatively high in all five clusters, the expression levels of chondrogenic markers were more variable, being the lowest in cluster 2. Overall, the scRNA-seq 
A.

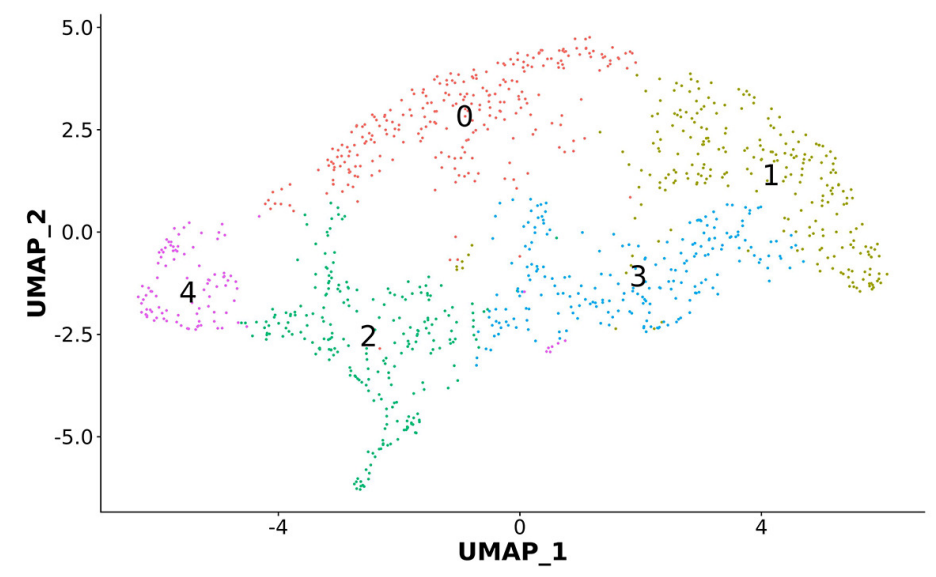

C.

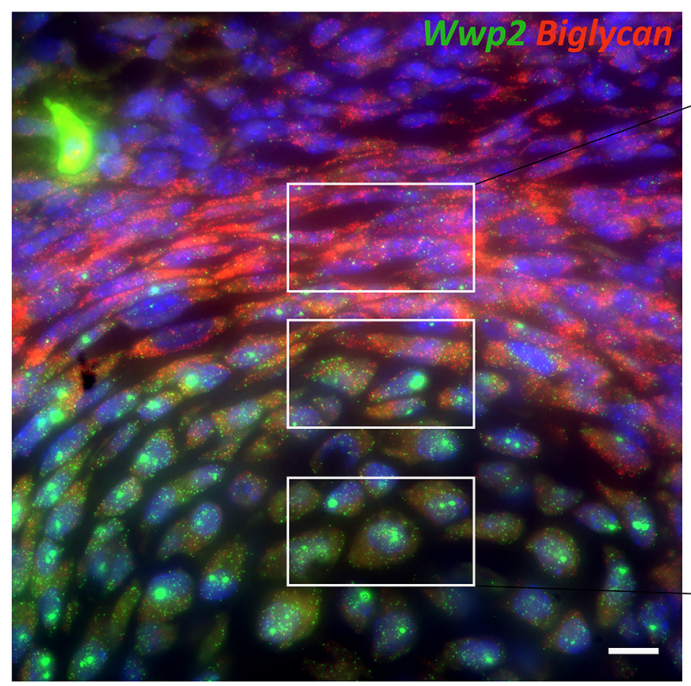

B.
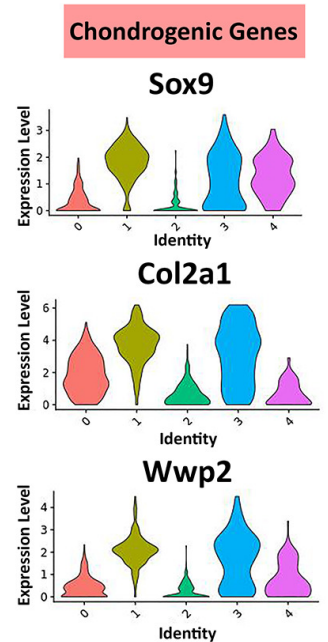

D.

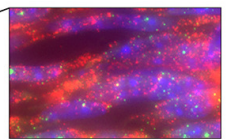

Tendon

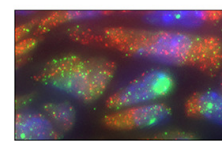

Attachment

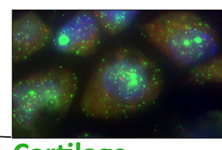

Cartilage
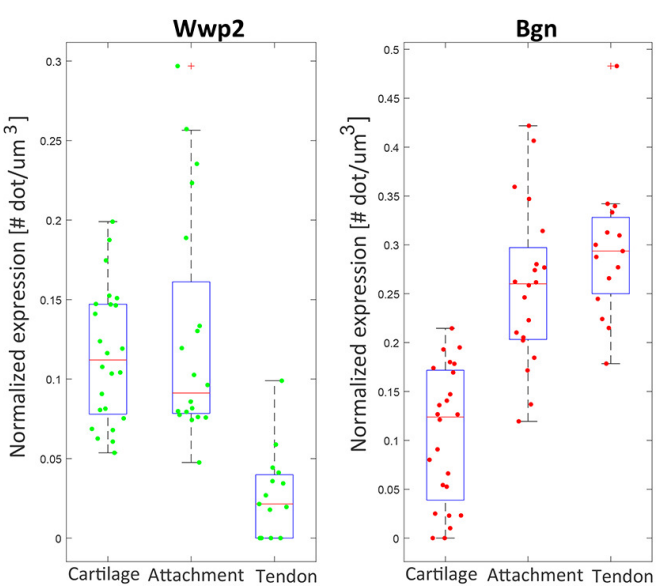

Cartilage Attachment Tendon
Tenogenic Genes

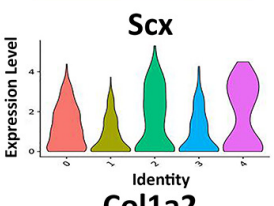

Col1a2

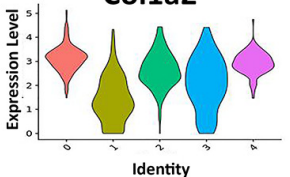

Bgn

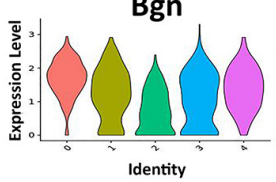

Figure 2. Attachment cells co-express tendon and cartilage genes at the single-cell level. (A) scRNA-seq analysis of E13.5 Sox9+/Scx+ attachment progenitors is shown as uniform manifold approximation and projection (UMAP) embedding of jointly analyzed single-cell transcriptomes (10x Chromium platform). (B) Violin plots of distinct genes associated with tendon or cartilage. (C) Single-molecule fluorescent ISH (smFISH) of mRNA of tendon biglycan (Bgn, red) and cartilage Wwp2 (green) genes on the background of DAPI staining (blue) further validates the dFISH results. X100 magnification, scale bar: $10 \mu \mathrm{m}$. (D) Quantification of Bgn and Wwp2 smFISH results in cartilage, attachment, and tendon cells.

The online version of this article includes the following figure supplement(s) for figure 2:

Figure supplement 1. Single-cell RNA-Seq (10x Chromium platform) on E13.5 Sox9+Scx+ attachment progenitors.

results suggest that the $\mathrm{Sox} 9^{+} / \mathrm{Scx}+$ attachment progenitors are bi-fated. The analysis also revealed a molecular sub-classification of this progenitor population.

Finally, to confirm the co-expression of tenogenic and chondrogenic genes at the attachment site at a single-cell resolution, we performed single-molecule FISH for Wwp2 (chondrogenic marker) and Bgn (tenogenic marker). As seen and quantified in Figure 2C,D, Wwp2 and Bgn were indeed coexpressed in the attachment cells.

Overall, these results indicate that attachment cells are bi-fated, expressing in parallel both chondrogenic and tenogenic genes (referred to in the following as mixed transcriptome or mixed expression profile). 


\section{Genome-wide profiling of attachment cell-specific regulatory regions}

To gain a mechanistic understanding of how attachment cells activate a combination of two transcriptomes, we compared chromatin accessibility in these cells with open chromatin signatures defining chondrocytes and tenocytes by conducting an assay for transposase-accessible chromatin with high-throughput sequencing (ATAC-seq) (Buenrostro et alı, 2015). This method allows to profile open chromatin regions, some of which may act as enhancers. To isolate by FACS E13.5 humeral chondrocytes, tenocytes and attachment cells, we generated a compound mouse line harboring Sox9-CreER, tdTomato, and Scx-GFP transgenes (Figure 1-figure supplement 1C-E). However, because the number of isolated chondrocytes was insufficient, chondrocytes were FACS-sorted from E13.5 Col2a1-CreER ${ }^{T}$-tdTomato-Scx-GFP mouse. These three cell populations were then subjected to ATAC-seq (see Materials and methods).

Initial PCA analysis of accessible chromatin profiles for each FACS-sorted cell population once again revealed that tenocytes and chondrocytes were clearly separated, while attachment cells resided between these two cell types (Figure 3-figure supplement 1A, Figure 1B). Next, we compared global chromatin accessibility among the three cell types by calculating the level of overlap among the ATAC-seq peaks (Figure 3A). While the majority of the peaks were shared by all three cell types, attachment cells had a significantly lower number of unique peaks $(p<1 e-4$ relative to both cell types, chi-square with Yates correction), and a significantly higher overlap with the other two cell types $(p<2.2 e-1)$.

Analysis of the ATAC-seq signal revealed that 13,017 peaks were located near transcription start sites (TSSs), whereas 31,856 peaks were in intergenic or intron regions. Most of the peaks that were located near TSSs were accessible in all three cell types (87\%), and only $13 \%$ were accessible in one or two cell types (Figure 3-figure supplement 1C,D).

Next, we studied the ATAC-seq signal of peaks associated with the genes that were differentially expressed at E14.5, using HOMER default parameters. We found that 819 peaks were located near transcription start sites (TSSs), whereas 2340 peaks were in intergenic or intron regions. Most of the peaks that were located near TSSs $(708,86 \%)$ were accessible in all three cell types, and only 111 $(13 \%)$ were accessible in one or two cell types (Figure $3 B, C$ ). This low level of differential accessibility is inconsistent with the possibility that promoter accessibility is the main mechanism regulating the bi-fated attachment cells. Interestingly, a significantly higher fraction of intergenic peaks were specific to one or two cell types $(1767,74.7 \%, p=0$, chi-square test, Figure $3 B, C)$.

Out of these 1767 intergenic peaks, 920 peaks were accessible in attachment cell; 672 were shared with either tenocytes or chondrocytes; and 248 were accessible only in attachment cells (Supplementary file 3). These results suggest that the 920 intergenic elements that were accessible in attachment cells may act as enhancers that drive the transcriptome of these cells. Moreover, since most of these intergenic elements were shared between attachment cells and either chondrocytes or tenocytes, they may serve as part of the mechanism that drives the mixed transcriptome of attachment cells.

To identify such dual cell-type-specific enhancers likely regulating attachment cell differentiation, we next screened for shared enhancers of 15 bona fide markers of tenocytes or chondrocytes that were found to be expressed in E14.5 attachment cells (Figure 1C). To improve the prediction of these enhancers, we selected our ATAC-seq peaks based on their proximity to genes with verified expression in attachment cells and another cell type (Figure 1-figure supplement 4, Figure 1D) and computationally intersected them with ENCODE datasets of histone modification marks associated with enhancers and promoters in mouse limbs at E13.5 (H3K27Ac, H3K9ac, H3K4me3, H3K4me1 ChIP-Seq), and other datasets (Andrey et alo, 2017; Guo et al., 2017; Figure 4 and Table 1), revealing the degree of evolutionary conservation of each core sequence (Casper et al., 2018). For example, as shown in Figure 3D, we identified a region at $-42 \mathrm{~kb}$ from the TSS of Mgp, a bona fide chondrogenic marker (Barone et al., 1991), which was accessible in chondrocytes and attachment cells, whereas in tenocytes this site was closed. Another example is Sox9, a bona fide chondrogenic marker. At $+303 \mathrm{~kb}$ from Sox9, we identified a region that was accessible in attachment cells and chondrocytes, but not in tenocytes. The same pattern was observed for a region at -330 kb from the TSS of a third bona fide chondrogenic marker, namely Col11a1 (Li et alo, 1995). The opposite pattern was observed at $-17 \mathrm{~kb}$ from the TSS of Col1a2, a bona fide tenogenic marker, where we identified a region that was accessible in attachment cells and tenocytes, but not 


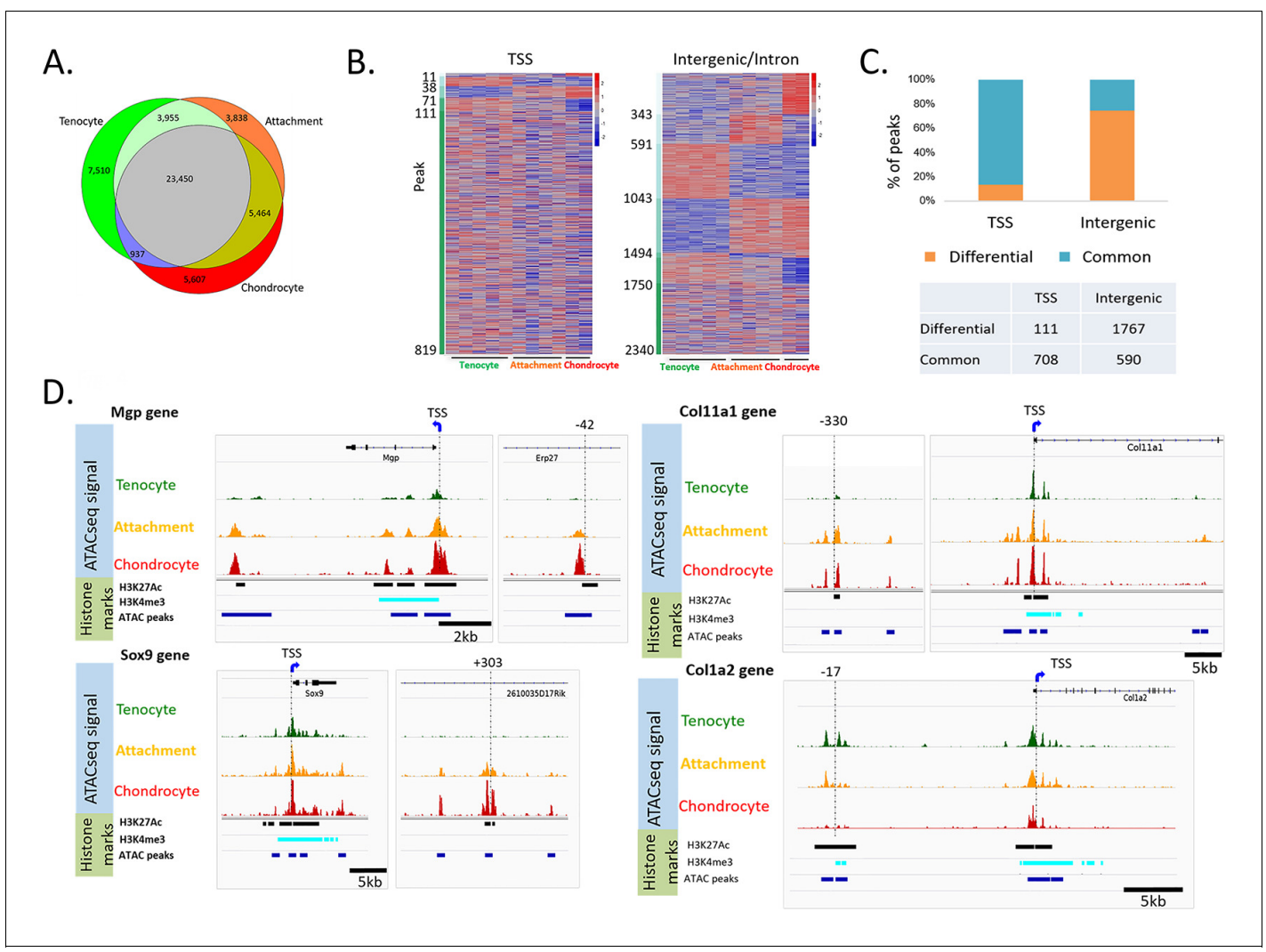

Figure 3. Accessible chromatin reveals an epigenetic mechanism shared by attachment cells and neighboring tenocytes or chondrocytes. (A) Venn diagram showing cell-specific or overlapping peaks of ATAC-seq among tenocytes, chondrocytes and attachment cells. (B) Heatmap of ATAC-seq peaks associated with E14.5 differentially expressed genes. Left: TSS peaks, right: intergenic or intron peaks. The peaks are sorted according to their degree of accessibility across the three cell types. (C) Percentage of common peaks (shared by three cell types) vs. differential peaks (the chromatin is open only in one or two cell types) compared between TSS and intergenic areas ( $p=0$, chi-square test). (D) IGV snapshots of the TSS region of Mgp, Sox9, Col11a1, and Col1a2 genes, as well as potential enhancers of these genes.

The online version of this article includes the following figure supplement(s) for figure 3 :

Figure supplement 1. Accessible chromatin reveals an epigenetic mechanism of shared enhancers by attachment cells and neighboring tenocytes or chondrocytes.

in chondrocytes. Similar results were obtained for additional chondrogenic markers, such as Sox6, and for tenogenic markers Tnc and Col1a1 (data not shown). Importantly, we found that the chromatin accessibility patterns of these putative enhancers were in agreement with the transcriptomic and ISH results, as shown, for example, by Sox9 and Col5a1 (Figure 1C,D, Figure 1-figure supplement 4). This suggests that the mechanism for the activation of a mixed transcriptome in attachment cells is based on sharing regulatory elements with chondrocytes or tenocytes.

\section{Shared regulatory elements drive expression in attachment cells and flanking cartilage or tendon cells}

The identification of multiple predicted enhancer regions near genes expressed by attachment cells and tenocytes or chondrocytes suggests that attachment cells are regulated predominantly by enhancers with shared activities. To test this hypothesis in vivo, we took advantage of a recently developed, site-directed transgenic mouse enhancer reporter system (Kvon et al., 2020). Using this system, we studied the activity of eight elements, which were selected because they were associated with bona fide marker genes for tenocytes or chondrocytes, and were found to be expressed in the attachment cells. Moreover, they were predicted to drive transcription in attachment cells and one of the flanking tissues (Figure 3D). The activity of these representative elements was examined at 


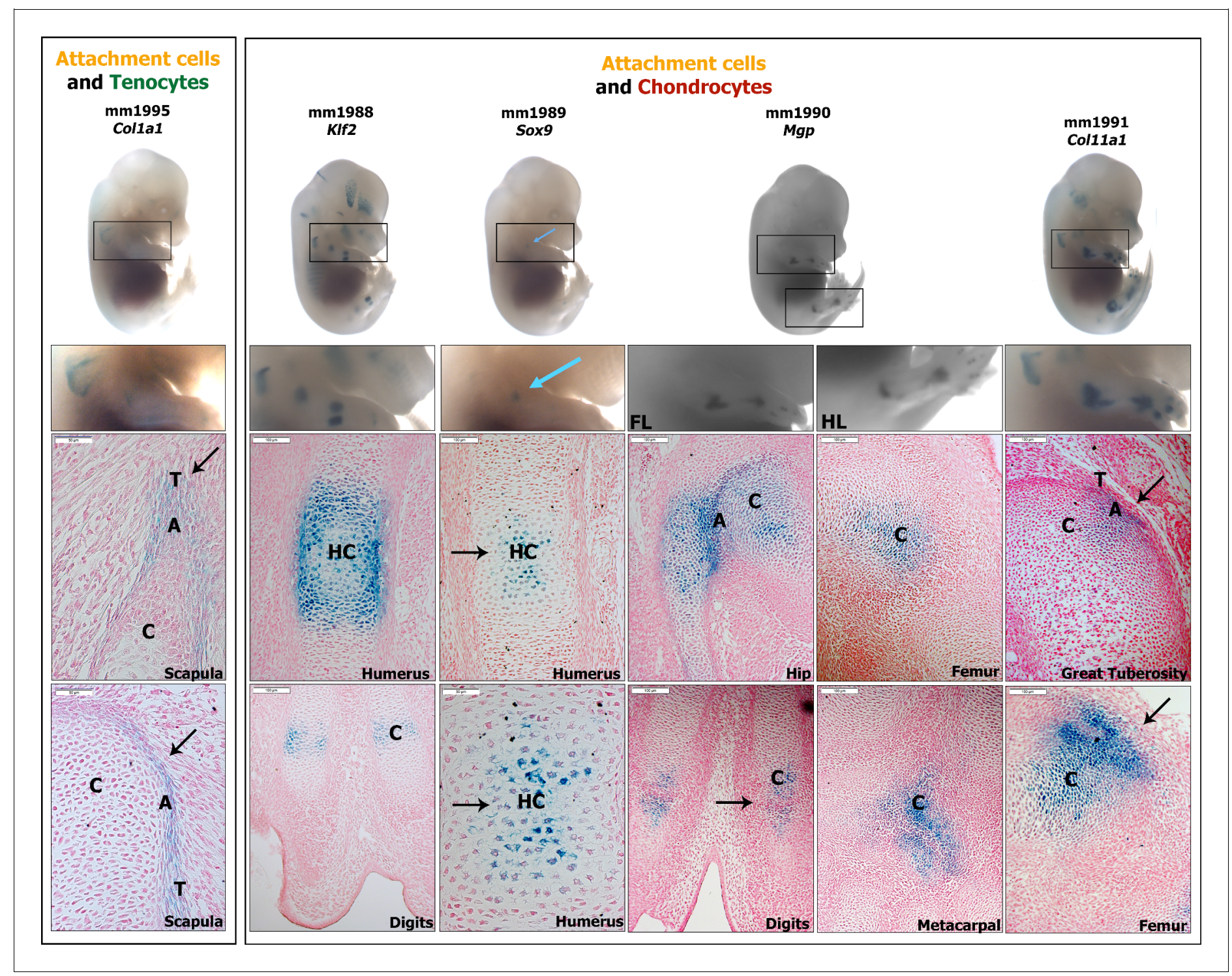

Figure 4. In vivo analysis of enhancers identifies shared domains of activity between attachment cells and neighboring tissues. Transgenic mouse reporter enhancer assay (lacZ) of elements positive at E14.5 (marked in light blue; for each enhancer, an E14.5 whole-mount embryo, magnification of the limb and forelimb and/or hindlimb sagittal sections are shown). Left to right: Col1a1 element (mm1995) activity is seen at the teres major insertion at the scapula $(n=2 / 9)$. Klf2 element (mm1988) activity is seen in hypertrophic chondrocytes and perichondrium at the humerus and forelimb digits ( $=3 /$ 3). Sox9 element (mm1989) activity is seen in hypertrophic chondrocytes of the humerus ( $n=4 / 7)$. Mgp element (mm1990) activity is seen in the hip, digit, and metacarpals joints in addition to the posterior distal side of the femur ( $n=3 / 3)$. Col11a1 element (mm1991) activity is seen in the greater tuberosity insertion and anterior distal side of the femur ( $n=11 / 11)$. T, tendon; $C$, cartilage; $A$, attachment; HC, hypertrophic chondrocytes.

E14.5, a stage at which chondrocytes, tenocytes, and attachment cells have already been established.

Five elements were found to be active in the mouse forelimbs, as well as in other anatomical areas (Figure 4). The Col1a1-associated element drove lacZ expression at the teres major insertion into the scapula, in agreement with the ATAC-seq results, which predicted its activity in tenocytes and attachment cells $(n=2 / 9)$. This result suggests that Col1a1 element is active in tenocytes and attachment cells. Klf2 and Sox9 elements were predicted to be active in chondrocytes and attachment cells (Figure 3D). The Klf2 element indeed drove reporter activity in hypertrophic chondrocytes and perichondrium at the humerus and forelimb digits, in addition to the skull and mandible (Figure 4, $n=3 / 3$ ). The Sox9 element showed activity solely in hypertrophic chondrocytes of the humerus ( $n=4 / 7$ ). These results suggest a chondrocyte-specific function of these two enhancers. 
Table 1. Criteria that were used to select candidates for the in vivo enhancer activity assay.

We first compared the ATAC-seq data to bulk MARS-seq transcriptome analysis and chose peaks that were assigned to genes with differential expression (using GREAT). According to the ATAC-seq results, the TSS of most of these genes was accessible in all three tissue types. Therefore, we searched for putative enhancers that could regulate the differential gene expression. We then compared the elements overlap with E13.5-E14.5 histone marks (H3K27Ac or H3K4me1 of ENCODE) and HiC results (Andrey et al., 2017), to increase the probability of in vivo verification, in addition to preliminary results of gene expression (i.e. the chosen elements were assigned to genes of interest, which were identified by RNA-seq and validated by ISH). The degree of evolutionary conservation of the core sequence was also taken into consideration while prioritizing the elements.

\begin{tabular}{|c|c|c|c|c|c|c|c|}
\hline & $\begin{array}{l}\mathrm{mm1995} \\
\text { Col1a1 }\end{array}$ & $\begin{array}{l}\mathrm{mm} 1988 \\
\text { KIf2 }\end{array}$ & $\begin{array}{l}\operatorname{mm1989} \\
\text { Sox9 }\end{array}$ & $\begin{array}{l}\operatorname{mm1} 1990 \\
\text { Mgp }\end{array}$ & $\begin{array}{l}\text { mm1991 } \\
\text { Col11a1 }\end{array}$ & $\begin{array}{l}\text { mm1992, } \\
\text { mm1994, Eln }\end{array}$ & $\begin{array}{l}\operatorname{mm} 1986 \\
\text { lgfbp5 }\end{array}$ \\
\hline $\begin{array}{l}\text { Distance from } \\
\text { TSS }\end{array}$ & $-63,010$ & $-30,343$ & 303,066 & $-42,288$ & $-331,264$ & $\begin{array}{l}-3,433 \\
-43,487\end{array}$ & $-3,605$ \\
\hline Coordinate & $\begin{array}{l}\text { Chr11:94872064- } \\
\text { 94874364 }\end{array}$ & $\begin{array}{l}\text { Chr8: } 72287698- \\
\text { 72291754 }\end{array}$ & $\begin{array}{l}\text { Chr11:113084290- } \\
113086290\end{array}$ & $\begin{array}{l}\text { Chr6:136917343- } \\
136918843\end{array}$ & $\begin{array}{l}\text { Chr3: } 113698476- \\
113700076\end{array}$ & $\begin{array}{l}\text { Chr5: 134749924- } \\
\text { 134751424 } \\
\text { Chr5: } 134790228- \\
\text { 134791228 }\end{array}$ & $\begin{array}{l}\text { Chr1: } 72877526- \\
72879452\end{array}$ \\
\hline $\begin{array}{l}\text { Encode } \\
\text { H3K27ac/ } \\
\text { H3K4me1 }\end{array}$ & + & + & + & + & + & + & + \\
\hline $\mathrm{HiC}$ & & + & & & & & \\
\hline $\begin{array}{l}\text { Core seq } \\
\text { conservation }\end{array}$ & Opossum & Chicken & Platypus & Opossum & Lizard & Opossum & Chicken \\
\hline $\begin{array}{l}\text { Klf2 binding } \\
\text { site }\end{array}$ & + & + & + & - & - & & \\
\hline
\end{tabular}

Mgp element was also predicted to be active in chondrocytes and attachment cells (Figure 3D). Its activity was seen in forelimb and hindlimb, specifically in hip, metacarpal joints and digits as well as in the posterior distal side of the femur, a site where ligaments (e.g. the cruciate ligaments) are inserted into the femur at the knee area and at ligament insertion into to the hip (e.g. iliofemoral ligament; Figure 4, $n=3 / 3$ ), verifying its activity in chondrocytes and attachment cells. Lastly, Col11a1 element activity was predicted in chondrocytes and attachment cells (Figure 3D). Its activity verified the bioinformatic analysis, showing LacZ staining in the greater tuberosity insertion, as well as in the posterior side of the skull, the nasal bone area and the anterior distal side of the femur (Figure $4, n=11 / 11$ ).

These results suggest that Mgp and Col11a1 elements are active in chondrocytes and attachment cells, whereas Col1a1 element is active in tenocytes and attachment cells, as the chromatin analysis predicts. Overall, these results provide a proof of concept for the ability of the accessible intergenic elements we have identified to act as enhancers that drive expression in both attachment cells and chondrocytes or tenocytes. This supports our hypothesis that shared enhancers activate a mixed transcriptome in attachment cells.

\section{Krüppel-like factors are regulators of attachment cell development}

Our finding of enhancers that can drive the transcription of the mixed transcriptome of the attachment cells raised the question of the identity of the transcription factors (TFs) that can potentially bind to these elements. To identify such factors, we used Genomatix to analyze accessible elements that were associated with differentially expressed genes for over-representation of transcription-factor-binding sites (TFBS), selecting the top 50 TFBS families, and then mining our transcriptomic data for the expression of these TFBS families (see Materials and methods). Among the differentially expressed genes at E14.5 we identified NFls (Nfia), GLls (Gli1), KLFs (Klf2 and Klf4), ZBTBs (Zbtb48) and RUNXs (Runx3; Table 2, Figure 5A), whose expression was upregulated in attachment cells. Further support for these results was provided by HOMER motif analysis (Heinz et alı, 2010), which showed significant over-representation of KLFs and RUNXs TFBSs. We therefore sought to explore the possible role of KLFs as regulators of attachment cells.

Focusing on Klf2, which was found to be differentially expressed by the bulk transcriptome analysis of the attachment site (Figure 1-figure supplement 2, Figure 1-figure supplement 3), we first 
Table 2. Genomatix analysis of the genomic regions of cis-regulatory elements identified by ATACseq.

Over-representation of transcription factor binding site (TFBS) families was identified. Crossing these results with E14.5 transcriptome revealed differentially expressed TFs from the KLF (Klf4 and Klf2), GLI (Gli11), NFI (Nfia), ZBTBs (Zbtb48), and RUNX families.

\begin{tabular}{llll} 
TFBS & Gene family & Description & Zinc finger \\
\hline V\$E2FF & Myc & E2F-myc activator/cell cycle regulator & no \\
\hline V\$KLFS & KLF & Krüppel-like transcription factors & yes \\
\hline V\$ZF02 & Zbtb & C2H2 zinc finger transcription factors & yes \\
\hline V\$NF1F & Nfi & Nuclear factor 1 & yes \\
\hline V\$MAZF & Maz, Patz1 & Myc-associated zinc fingers & yes \\
\hline V\$GLIF & GLI & GLI zinc finger family & yes \\
\hline V\$PLAG & Plag1, Plag2, Plagl1 & Pleomorphic adenoma gene & yes \\
\hline V\$HAML & Runx & Acute myelogenous leukemia factors & no \\
\hline V\$NFKB & HIVEP & Nuclear factor kappa B/c-rel & yes \\
\hline V\$SMAD & Smad & Vertebrate SMAD family of transcription factors & no
\end{tabular}

validated its expression in the forming attachment site by ISH (Figure 5B). Next, we analyzed the enhancers that were shown by the bioinformatic analysis to be active in attachment cells and either tenocytes or chondrocytes (Figure 4). Three of these enhancers had Klf2-binding sites in their sequence (Table 1), further supporting a potential role for KLFs during attachment site development.

Previous studies demonstrated that KIf2 and Klf4 are functionally redundant, as KLF4 has $\sim 90 \%$ sequence similarity to KLF2 in its zinc finger DNA-binding domain, suggesting that these factors could have common target sequences (Chiplunkar et al., 2013). In our scRNA-seq analysis, the expression of both genes was found in Sox $9+/ S c x+$ attachment progenitors (Figure 5C). We therefore proceeded to study attachment cell development upon blocking the expression of both Klf2 and Klf4 in limb mesenchyme, using Prx1-Cre as a deleter and focusing on E15.5 and E18.5, a period during which the attachment site of the deltoid tuberosity undergoes differentiation and consequently grows in size. Transverse histological sections through the deltoid tuberosity of E15.5 control mice showed that the attachment cells were packed together and surrounded by ECM (Figure 5Da'). In contrast, in the putative attachment site of Prx1-Klf2-Klf4 double conditional knockout (dcKO) embryos, the cells were sparse with reduced ECM (Figure 5Db'). By E18.5, this difference was more pronounced, as attachment cells failed to differentiate (Figure 5Dc', $d$ '). To gain a molecular understanding, we studied the expression of several genes that were previously shown to be expressed at these stages in the attachment site (Felsenthal et al., 2018; Figure 1D). Indeed, we found that the expression of Col1a1, Gli1, Bsp, Bgn, and Col5a1 was reduced in the dcKO attachment site, relative to the control (Figure 5De-p), supporting a role for KLF2/4 in attachment cells differentiation.

Finally, to further validate the involvement of KLFs in activation of gene expression in the attachment site, we searched for KLF2/4 binding sites in ATAC-seq peaks associated with the 374 genes that were shown to be expressed by attachment cells (Figure 1C). Interestingly, we found that many of these genes had KLF2/4 binding sites in their regulatory regions ( $72 \%$ of the 374 attachment genes relative to $53 \%$ in the whole genome, $p<1 e-4$, chi-square). We then searched for KLF2/4 binding sites in ATAC-seq peaks that were associated with genes whose expression was reduced in the dcKO attachment site (Figure 5De-p). For Gli1, we found KLF2/4 TFBSs in peaks that reside -2.1 and $-1.5 \mathrm{~kb}$ from its TSS (Table 3). For Col5a1, we found multiple binding sites for KLF2 or KLF4. Together, these results indicate that KLF2/4 play an essential role in regulating attachment cell gene expression.

Combined with the bioinformatic analysis of chromatin and transcriptomic data, these results suggest that KLF2/4 are major regulators of tendon-to-bone attachment, playing a central role in attachment cell differentiation. 
A.

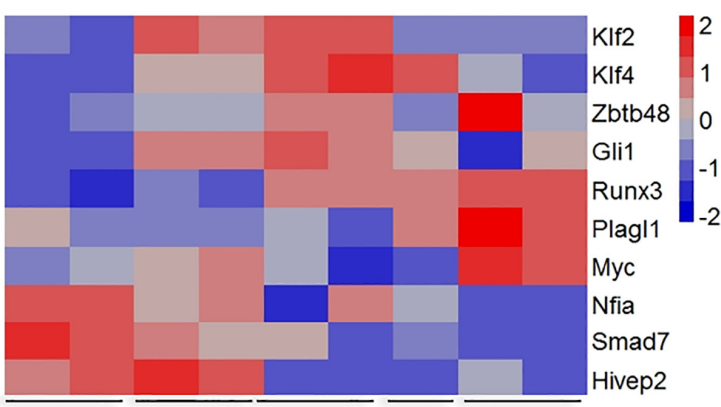

B.

$\square$ R.Tenocyte $\bullet$ A.Tenocyte $\bullet$ Attachment $\bullet$ A. Chond. $\square$ R.Chon
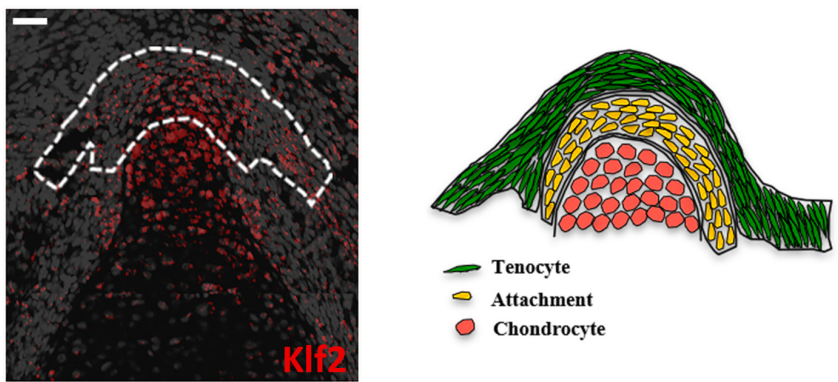

Tenocyte

Chondrocyte

C.

KIf2

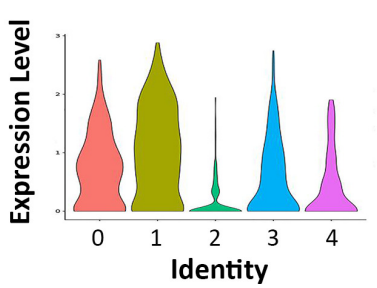

D.

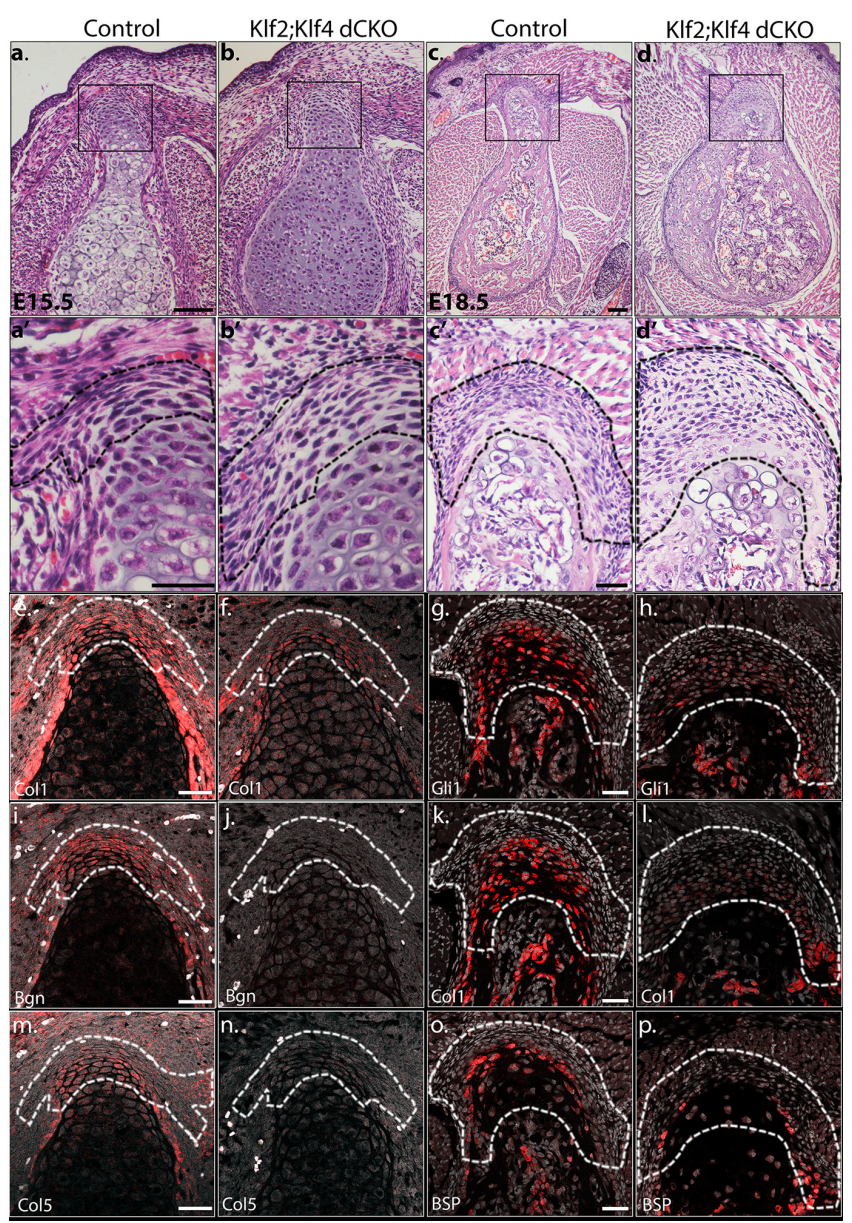

Figure 5. Krüppel-like factors (KLFs) are regulators of attachment cell development. (A) Heatmap of selected transcription factors at E14.5.

Transcriptome analysis shows upregulated expression of KIf2, Klf4, and Gli1 in attachment cells. (B) Left: E14.5 ISH validated these results, showing Klf2 expression in attachment cells (X20 magnification, scale bar: $25 \mu \mathrm{m}$ ). Right: Scheme of attachment site. (C) Single-cell RNA-seq analysis of E13.5 Sox9 $+\mathrm{Scx}+$ attachment cells shows Klf2 and Klf4 expression in the five cell populations. (D) KLF2 and KLF4 are regulators of attachment cell development. a-d. Histological transverse sections through the humeral deltoid tuberosity of E15.5 Prx1-KIf2-KIf4 and E18.5 Prx1-KIf2-KIf4 mutant and control embryos ( $\times 10$ and $\times 5$ magnification, scale bar: $100 \mu \mathrm{m})$. a'-d'. Higher magnification of upper panel ( $\times 40$ for E15.5 and $\times 20$ for E18.5, scale bar: $40 \mu \mathrm{m})$. e-p. ISH for Col1a1 and Bgn genes of E15.5 Prx1-KIf2-KIf4 mutant and control embryos. ISH for Gli1, Col1a1, and Bsp genes of E18.5 Prx1-Klf2-Klf4 mutant and control embryos ( $\times 20$ magnification, scale bar: $40 \mu \mathrm{m})$.

\section{Discussion}

In this work, we describe the unique transcriptome that allows cells of the attachment between tendon and bone to act as a transitional tissue. The ability to activate a combination of chondrogenic and tenogenic transcriptomes is regulated by sharing enhancers with these cells. Finally, we identify the transcription factors KLF2/4 as regulators of these unique bi-fated cells.

The existence of borders between tissues that differ in cell type, extracellular matrix composition, structure, and function raises the question of how tissues are connected. The border can be sharp, as seen in blood vessels, where pericytes and endothelial cells are separated by a basement membrane, or between the esophagus and the stomach in the gastrointestinal tract (Bergers and Song, 2005; San Roman and Shivdasani, 2011). On the other hand, the border can be less defined histologically and molecularly, thus forming a transitional tissue. Examples for the latter are the borders between the sections of the small intestine and between tendon and bone (Liu et al., 2007; 


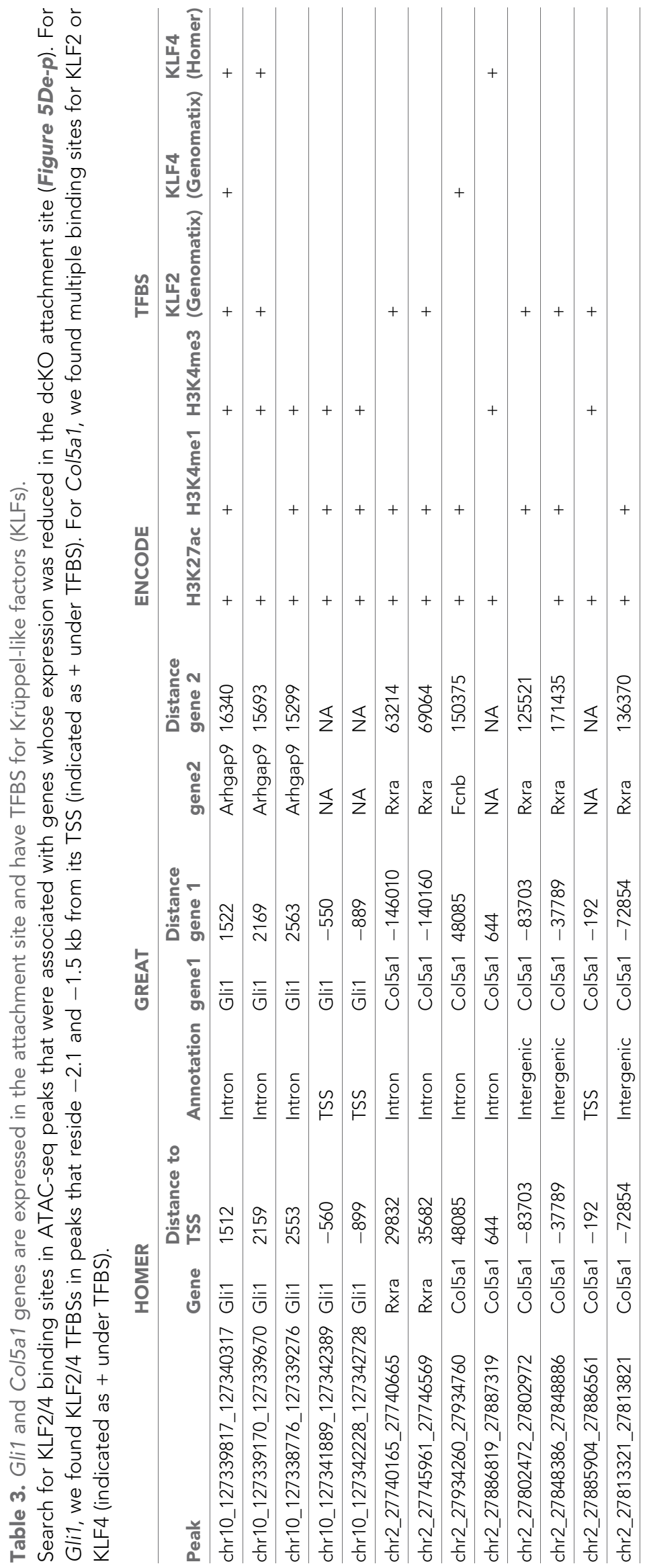


Romih et al., 2005; San Roman and Shivdasani, 2011). From a broader perspective, as all organs and systems are made of different tissues, understanding the biology of border tissues is imperative. Moreover, some of these border tissues are involved in various pathologies. For example, gastric cancers may emerge from distinct anatomical areas, such as the esophagus-stomach boundary (Chawengsaksophak, 2019; McDonald et al., 2015; San Roman and Shivdasani, 2011).

In the case of the attachment between tendon and bone, the significance of this tissue is demonstrated by enthesopathies, a collective name for injuries and pathologies of the enthesis. For example, over $30 \%$ of the population over the age of 60 will injure their shoulder's rotator cuff (Lehman et al., 1995). Failure rates of surgical reattachment range from $20 \%$ for small tears to $94 \%$ for repair of massive tears (Galatz et al., 2004; Harryman et al., 1991). The high failure and recurrence rates of these procedures highlight the need for understanding the biology of this complex transitional tissue of the enthesis. This understanding may allow the development of new strategies to improve the treatment of enthesopathies.

There are two options to form a transitional tissue. The first strategy is by mixing cells from the two neighboring tissues, such as in the epithelia of the urinary tract (Romih et al., 2005). Alternatively, the border cells can express a mixture of the transcriptomes of the two neighboring cell types. As we show here, the attachment cells represent the latter strategy well, as they express a high number of genes that are differentially expressed by either tenocytes or chondrocytes. These cells display morphological features that are shared with tenocytes and chondrocytes (Thomopoulos et al., 2010). Our results therefore provide a molecular explanation for the age-old histological definition of enthesis cells as fibrocartilage, which was based on their morphology (Thomopoulos et al., 2010). Moreover, the finding of mixed matrix genes in the transcriptome of the attachment cells may provide a mechanism for the formation of a transitional tissue, which allows safe transfer of forces by the tendon between muscle and bone.

In addition to expression of chondrogenic and tenogenic genes, we identified genes that are uniquely expressed by attachment cells. These genes may provide another level of specificity to the regulation of the development of this unique tissue. Finally, our scRNA- seq of the attachment cells revealed heterogeneity, which was a consequence of varying levels of chondrogenic and tenogenic gene expression. This heterogeneity may represent the differentiation processes that the Sox9/Scxpositive progenitors undergo during development, ultimately leading to their terminal cell fate.

Our finding that attachment cells are bi-fated raises the question of the mechanism that underlies this fate. An immediate implication of our finding is that there must be an epigenetic mechanism that supports the bi-fated state. The observed chromatin accessibility at the sites of the promoters of most of the shared genes in all three cell types rules out the possibility of limited promoter accessibility as the main mechanism. By contrast, the high percentage of shared accessible intergenic sites between attachment cells and one group of flanking cells, that is chondrocytes or tenocytes, suggests that this is the main mechanism. Moreover, many of these shared sites correlated with putative enhancers in ENCODE datasets. Finally, we verified the ability of three different enhancers from that list to drive gene expression in attachment cells and in either tendon or cartilage. These findings strongly support our hypothesis that the regulatory mechanism is based on the ability of attachment cells to share enhancers with either chondrocytes or tenocytes in order to drive the mixed expression profile of these bi-fated cells. It is important to emphasize that we have also identified a group of intergenic elements that were accessible exclusively in attachment cells. These attachment-specific elements may act as enhancers that drive the expression of genes that are specific to attachment cells. It is, of course, possible that they participate in the regulation of shared genes as well. Overall, both sets of putative enhancers, namely shared and attachment cell-specific, may play important roles in the genetic program that regulates the development of this unique tissue.

Sharing enhancers is not the only possible strategy for the generation of a mixed transcriptome. A simple alternative would be a specific set of enhancers to be used by the attachment cells. A possible explanation for the sharing strategy is the common origin of all these cells, which is limb mesenchyme originating from lateral plate mesoderm (Johnson and Tabin, 1997). It is possible that during development, limb mesenchymal progenitors display highly accessible chromatin; yet, during differentiation, this accessibility is restricted to prevent the expression of genes from alternate lineages. In contrast to this restriction process, in the bi-fated attachment cells the shared sites are maintained accessible to allow the expression of the mixed transcriptome. A mechanism for silencing of genes of alternate lineages was previously described. For example, polycomb-repressed chromatin 
leads to silencing of genes of alternate lineages, leading to the commitment to a specific cell fate (Aldiri et al., 2017; Laugesen and Helin, 2014; Zhu et al., 2013). Interestingly, previous studies demonstrated the importance of chromatin repression in the developing limb, showing how deletion of Ezh2, which acts as the enzymatically active subunit of PRC2, leads to skeletal malformations (Deimling et al., 2018). This obviously raises the question of the mechanism that prevents this silencing in attachment cells.

It is clear that we cannot exclude the possibility that an active mechanism, such as the SWI/SNF remodeling complexes, opens the chromatin structure in bi-fated cells to allow attachment cell dual behavior (Hu et al., 2011). However, such a mechanism cannot explain why the strategy of shared enhancers was selected. Finally, a mixed transcriptome is one of the hallmarks of stem cell pluripotency, as progenitor cells eventually chose one fate over the other upon differentiation (Johnson et al., 2015; Soldatov et al., 2019). Our findings suggest a different strategy, where using both programs facilitates the establishment of a specific attachment tissue. Overall, our results reveal a novel function for chromatin state, which allows the activation of two sets of genes in a third cell type to create a new cell fate that forms a transitional tissue.

KLF2 and KLF4 are known to regulate several biological processes, such as promoting the differentiation of gut and skin (KLF4, [Katz et al., 2002; Segre et al., 1999]) as well as the immune system (KLF2, [Kuo et al., 1997]), maintaining pluripotency of embryonic stem cells (KLF2 and KLF4, [Jiang et al., 2008]), and, together with other factors, inducing pluripotency to generate iPSC by reprogramming (KLF4, [Takahashi and Yamanaka, 2006]). Several works describe the involvement of KLF2 and KLF4 in the musculoskeletal system. In bones, Klf4 over-expression in osteoblasts caused delayed bone development, in addition to impaired blood vessel invasion and osteoclast recruitment (Michikami et al., 2012). Another study showed that KLF2/4 are expressed during chick limb development in tendons and ligaments as part of the genetic program that regulates connective tissues (Orgeur et al., 2018). Previous studies showed that KLF2 and KLF4 display high similarity in protein sequences (Dang et al., 2000; Shields and Yang, 1997), suggesting that these factors could have common target sequences and may be functionally redundant. Indeed, loss of both KLF2 and KLF4 during embryogenesis led to abnormal blood vessel development and early lethality. This phenotype was more severe than what was observed in embryos that lost only KLF2 or KLF4 (Chiplunkar et al., 2013). Furthermore, previous work identified 313 target genes shared between KLF2 and KLf4, suggesting that they overlap in regulating gene expression (Orgeur et al., 2018). In this work, we show that KLF2/4 are central regulators of the attachment site. While the attachment did form initially in their absence, the subsequent differentiation failed, suggesting that KLF2/4 play a role at this stage. While we concentrated in this study on the attachment site, it is most likely that KLF2/4 play a role also in other musculoskeletal tissues such as the skeleton, tendon, and muscle. This possibility is supported by previous studies, where KLF2/4 were shown to be expressed in osteoblasts, chondrocytes, tenocytes, and muscle connective tissues (Michikami et al., 2012; Orgeur et al., 2018). Previous studies demonstrate the role of muscle-induced mechanical load in the development of attachment site (Blitz et al., 2009). In that context, our finding that KLF2/4 regulate the differentiation of attachment cells is interesting, because previous works have shown that these factors are mechanically regulated. It was shown in mice that shear stress on the vessels induced by blood flow leads to upregulation of Klf2 expression (Lee et al., 2006). Additional in vitro studies showed that KLF2 and KLF4 are influenced by shear stress (Chiplunkar et al., 2013; Dekker et al., 2005; Villarreal et al., 2010). It is therefore possible that these factors are regulated by muscle forces, leading to the proper differentiation and maturation of the attachment site.

The ability of KLF2/4 to regulate gene expression in the attachment site is supported by our finding that many of the genes that were expressed by attachment cells had in their regulatory region KLF2/4 binding sites. Yet, it is clear that not all of them share this property, suggesting that these two factors are part of a larger transcriptional network. For example, our bioinformatic analysis identified other TF families such as GLI's, RUNX's, and NFI's as regulators of the attachment sites. Gli1 was previously reported as a marker for enthesis cells (Dyment et al., 2015; Felsenthal et al., 2018; Liu et al., 2012a; Schwartz et al., 2015). Since gene expression by attachment cells is regulated by sharing enhancers with chondrocytes or tenocytes, it is reasonable to assume that some regulators of these cells might be part of the network that regulates the attachment cells. Indeed, loss of the tendon regulator Scx in mice led to failure of attachment cells to differentiate. Additionally, loss of 
the chondrogenic regulator Sox 9 in Scx-expressing cells led to failure in attachment site formation (Blitz et al., 2013; Blitz et al., 2009).

To conclude, by characterizing the transcriptome and chromatin landscape of tendon-to-bone attachment cells, we provide a molecular understanding of the bi-fated identity of these cells. Moreover, by identifying the transcription factors KLF2/4 as central regulators and the strategy of sharing enhancers with either tenocytes or chondrocytes, we provide a mechanism that regulates these bifated cells (Figure 6). These findings present a new concept for the formation of a border tissue, which is based on the simultaneous expression of a mixed transcriptome of the two flanking cell types by the intermediate cells. This strategy allows the formation of a unique transitional tissue without developing de novo a dedicated genetic program that regulates a third, new cell fate.

\section{Materials and methods}

For Key Resources Table, see Appendix.

\section{Animals}

The generation of floxed Klf2 (Lee et al., 2006), floxed Klf4 (Katz et al., 2002), Prx1-Cre (Logan et alı, 2002), Sox9-CreER (Soeda et alı, 2010), Col2-CreER ${ }^{T}$ (Nakamura et al., 2006), Col2a1-Cre (Ovchinnikov et al., 2000), R26R-tdTomato (Madisen et al., 2010), and Scx-GFP (Pryce et al., 2007) mice have been described previously.

To create Col2a1-CreER, R26R-tdTomato, Sox9-CreER, R26R-tdTomato, and Col2a1-Cre, R26RtdTomato reporter mice, all on the background of Scx-GFP, floxed R26R-tdTomato mice were mated with Col2a1-CreER, Sox9-CreER or Col2a1-Cre mice, respectively. These strains were mated on a mixed background of C57BL/6 and B6.129 (ICR) mice and used for LCM and FACS experiments. To create Prx1-Klf2-Klf4 mutant mice, floxed Klf2-Klf4 mice were mated with Prx1-Klf2-Klf4

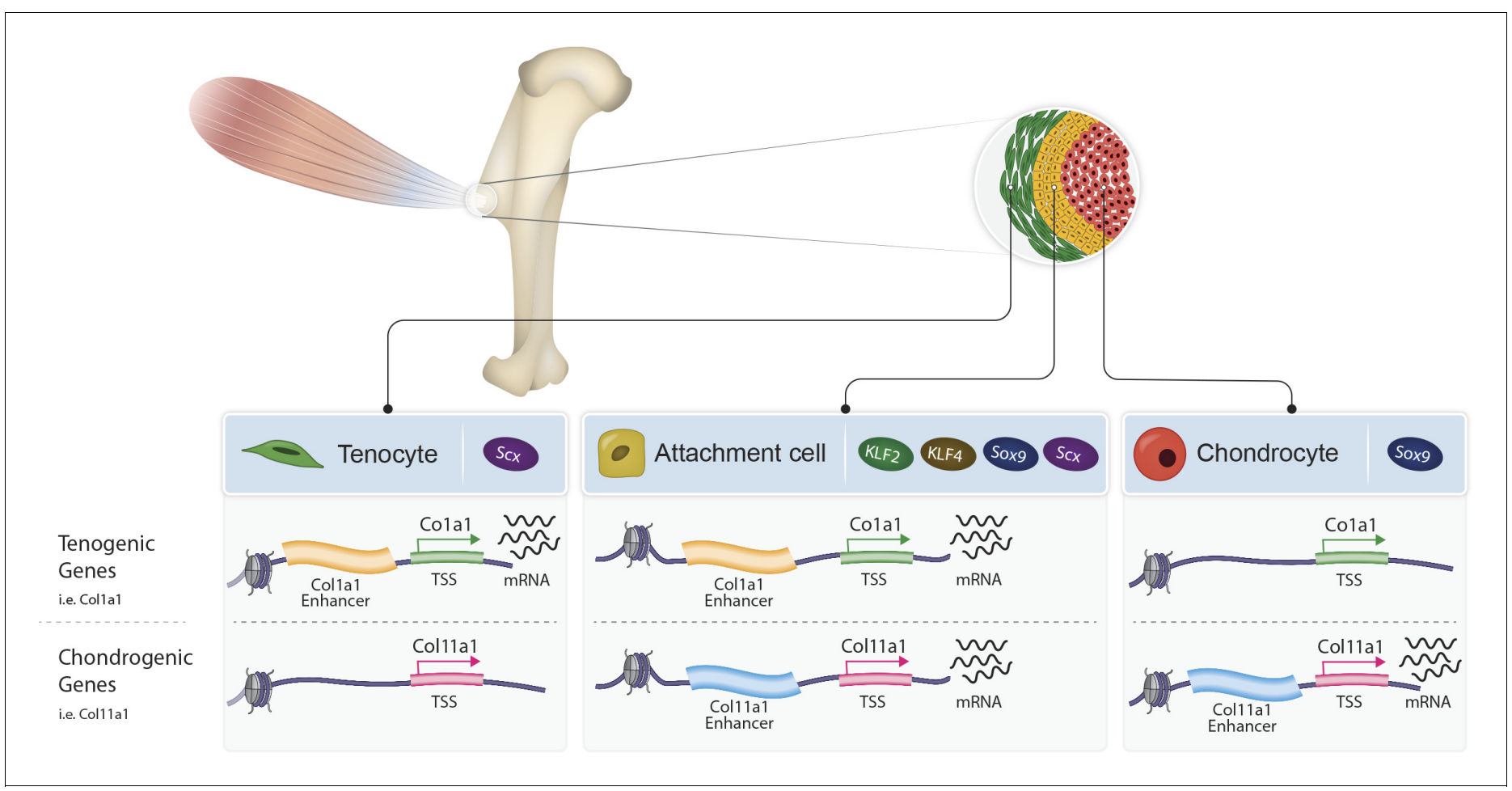

Figure 6. Proposed model of bi-fated tendon-to-bone attachment cells that are regulated by shared enhancers and KLF transcription factors. Tenocytes (green, left) and chondrocytes (red, right) express tenogenic (i.e. Col1a1) or chondrogenic (i.e. Col11a1) genes, respectively, whereas attachment cells (yellow, middle) express both chondrogenic and tenogenic genes to form the attachment site. Attachment cells duality of gene expression is regulated epigenetically by intergenic chromatin areas, which are accessible in these cells and in either tenocytes or chondrocytes. Additionally, at the transcriptional level, the transcription factors KLF2/4 are expressed by attachment cells and regulate their differentiation. 
mice. As a control, we used embryos that lack Cre alleles. E14.5 wild-type C57BL/6 mice were used for ISH experiments as well.

For FACS experiments, Sox9-CreER or Col2a1-CreER mice were crossed with Rosa26-tdTomato reporter mice, all on the background of Scx-GFP. Induction of Cre recombinase was performed at various pregnancy stages by administration of $0.03 \mathrm{mg} / \mathrm{gr}$ tamoxifen/body weight in corn oil by oral gavage (stock concentration was $5 \mathrm{mg} / \mathrm{ml}$ ). In all timed pregnancies, plug date was defined as E0.5. For harvesting of embryos, timed-pregnant females were sacrificed by cervical dislocation. Tail genomic DNA was used for genotyping by PCR.

\section{Laser capture microdissection}

E14.5 Col2a1-tdTomato-Scx-GFP mouse forelimbs were dissected, shortly fixated in 4\% PFA, washed with PBS and cryo-embedded (as described by Bhattacherjee et al., 2004 Bhattacherjee et al., 2004). Next, samples were cryo-sectioned and mounted on LCM slides (PET, Zeiss), washed with RNase-free water and EtOH (Arcturus dehydration component kit) according to an altered protocol of Pazin et al., 2012. LCM (PALM MicroBeam C system, Zeiss) was calibrated for refined tissue cutting. Isolated cells were collected to LCM caps (Adhesive Cap 500 clear, Zeiss) and RNA was purified using RNeasy FFPE Kit (Qiagen). The resulting RNA was the input for the bulk MARS-seq protocol (RNA sequencing).

\section{Preparation of single-cell suspension for fluorescence-activated cell sorting (FACS)}

Flow cytometry analysis and sorting were performed at the Weizmann Institute of Science Flow Cytometry Core Facility on a BD FACS Arialll instrument (BD Immunocytometry Systems) equipped with 488, 407, 561, and $633 \mathrm{~nm}$ lasers, using a $70 \mu \mathrm{m}$ nozzle, controlled by BD FACS Diva software v8.0.1 (BD Biosciences). Further analysis was performed using FlowJo software v10.2 (Tree Star). For collection of cells, Sox9-CreER ${ }^{T 2}$-tdTomato;ScxGFP or Col2a1-CreER-tdTomato;ScxGFP mice were crossed with Rosa26-tdTomato;ScxGFP reporter mice. Embryos were harvested at E13.5 following tamoxifen administration at E12.0, as described above. Forelimbs were dissected and suspended in cold PBS. To extract cells from tissues, PBS was replaced with $1 \mathrm{ml}$ heated $0.05 \%$ trypsin and collagenase type $\mathrm{V}$ (dissolved in DMEM, Sigma) and incubated for $15 \mathrm{~min}$ at $37^{\circ} \mathrm{C}$, gently agitated every $5 \mathrm{~min}$. Tissues were then dissociated by vigorous pipetting using $1 \mathrm{ml}$ tips. Next, $4 \mathrm{ml}$ of DMEM supplemented with 10\% FBS and 1\% Pen-Strep was added and cell suspensions were filtered with 40 $\mu \mathrm{m}$ filter net. Finally, tubes were centrifuged at $1000 \mathrm{rpm}$ for $7 \mathrm{~min}$, supernatant was removed and cells were resuspended in $0.5-1 \mathrm{ml}$ of cold PBS and used immediately for FACS. Single-stained GFP and tdTomato control cells were used for configuration and determining gate boundaries. Live cells were gated by size and granularity using FSC-A versus SSC-A and according to DAPI staining ( $1 \mu \mathrm{g} /$ $\mathrm{ml}$ ). FSC-W versus FSC-A was used to further distinguish single cells. In addition, unstained, GFPstained only and tdTomato-stained only cells were mixed in various combinations to verify that the analysis excluded false-positive doublets. GFP was detected by excitation at $488 \mathrm{~nm}$ and collection of emission using 502 longpass (LP) and 530/30 bandpass (BP) filters. tdTomato was detected by excitation at $561 \mathrm{~nm}$ and collection of emission using a 582/15 BP filter. DAPI was detected by excitation at $407 \mathrm{~nm}$ and collection of emission using a 450/40 BP filter.

\section{Real-time PCR (RT-PCR)}

Total RNA was purified from LCM-isolated samples of E14.5 mouse forelimbs using RNeasy FFPE Kit (Qiagen). Reverse transcription was performed with High Capacity Reverse Transcription Kit (Applied Biosystems) according to the manufacturer's protocol. Analysis of Col2a1 and Scx was performed to monitor RNA quality during LCM calibrations, whereas RNA quantity was monitored by analysis of $\beta$-actin. RT-PCR was performed using Fast SYBR Green master mix (Applied Biosystems) on the StepOnePlus machine (Applied Biosystems). Values were calculated using the StepOne software. Data were normalized to $18 \mathrm{~S}$ rRNA or $\beta$-actin in all cases.

\section{In situ hybridization}

Section ISH were performed as described previously (Riddle et al., 1993). Single-and double-fluorescent ISH on paraffin sections were performed using DIG- and/or FITC-labeled probes (listed in 
Table 4. List of probes used for in situ hybridization.

\begin{tabular}{llll} 
Probe name & Genomic position & Refseq template & Size (bp) \\
\hline Igfbp5 & 792-1264 & NM_010518.2 & 502 \\
\hline Col11a1 & $831-1224$ & NM_007729.3 & 393 \\
\hline Biglycan & $147-716$ & NM_007542.4 & 569 \\
\hline Wwp2 & $2488-3056$ & NM_025830.3 & 568 \\
\hline Col5a1 & $626-1298$ & NM_015734.2 & 672 \\
\hline Col1a1 & $4295-4475$ & NM_007742.4 & 180 \\
\hline KIf2 & $895-1512$ & NM_008452.2 & 617 \\
\hline Gli1 & $1810-2447$ & NM_010296.2 & 638 \\
\hline Bsp & $145-1058$ & NM_008318.3 & 1955 \\
\hline Scx & $273-1129$ & NM_198885.3 & 856 \\
\hline Mfap4 & $276-966$ & NM_029568.2 & 690 \\
\hline Ptn & $1247-1932$ & NM_008973.2 & 685 \\
\hline Col3a1 & $707-1388$ & NM_009930.2 & 681 \\
\hline Mgp & $69-553$ & NM_008597.4 & 485 \\
\hline Eln & $154-693$ & NM_007925.4 & 540 \\
\hline Mmp14 & $708-1283$ & NM_008608.3 & 575 \\
\hline Col2a1 & $4474-4879$ & NM_001113515.2 & 406 \\
\hline Col9a1 & $2553-3100$ & NM_007740.3 & 547 \\
\hline Sox9 & $50-797$ & NM_011448.4 & 748 \\
\hline Snorc & N2-437 & NM_028473.1 & 405 \\
\hline
\end{tabular}

Table 4; Shwartz and Zelzer, 2014). After hybridization, slides were washed, quenched, and blocked. Probes were detected by incubation with anti-DIG-POD (Roche; 1:300) and anti-FITC-POD (Roche, 1:200), followed by Cy2-tyramide- and Cy3-tyramide-labeled fluorescent dyes according to the instructions of the TSA Plus Fluorescent Systems Kit (Perkin Elmer).

\section{Single-molecule fluorescent in situ hybridization (smFISH)}

Harvested E14.5 forelimbs were fixed with cold 4\% formaldehyde (FA) in PBS and incubated first in $4 \%$ FA/PBS for $3 \mathrm{hr}$, then in $30 \%$ sucrose in $4 \%$ FA/PBS overnight at $4^{\circ} \mathrm{C}$ with constant agitation. Fixed tissues were embedded in OCT and sectioned at a thickness of $10 \mu \mathrm{m}$. The preparation of the probe library, hybridization procedure, and imaging conditions were previously described (Itzkovitz et al., 2012; Lyubimova et al., 2013; Raj et al., 2008). In brief, probe libraries were designed against biglycan (Bgn) and Wwp2 mRNA sequences using the Stellaris FISH Probe Designer (Biosearch Technologies, Inc, Petaluma, CA) coupled to Quasar 670 and CAL Fluor Red 610 , respectively. Libraries consisted of 17-96 probes each of length 20 bps, complementary to the coding sequence of each gene (Supplementary file 2). Nuclei were stained with DAPI. To detect cell borders, Alexa Fluor 488 conjugated phalloidin (Thermo Fisher, A12379) was added to the GLOX buffer, which was wash for 15 min. Slides were mounted using ProLong Gold (Molecular Probes, P36934).

\section{Image acquisition and analysis}

For smFISH image acquisition, we used a Nikon-Ti-E inverted fluorescence microscope equipped with a Photometrics Pixis 1024 CCD camera to image $10-\mu \mathrm{m}$-thick cryosections. For image analysis, we used ImageM, a custom MATLAB program (Lyubimova et al., 2013), which was used to compute single-cell mRNA concentrations by segmenting each cell manually according to the cell borders and the nucleus. The size of the nucleus was detected automatically by the program according to the DAPI signal. For each cell, the concentration of cytoplasmic mRNA of each gene was 
calculated by measuring the number of dots per volume. Images were visualized and processed using ImageJ $1.51 \mathrm{hr}$ (Schindelin et al., 2012) and Adobe Illustrator CC2018.

\section{Bulk RNA sequencing}

For this analysis, we adapted the MARS-seq protocol (Jaitin et al., 2014; Keren-Shaul et al., 2019) to generate RNA-seq libraries for expression profiling of the purified RNA from E14.5 LCM-isolated samples. Briefly, RNA from each sample was barcoded during reverse transcription and pooled. Following Agencourt Ampure XP beads cleanup (Beckman Coulter), the pooled samples underwent second strand synthesis and were linearly amplified by T7 in vitro transcription. The resulting RNA was fragmented and converted into a sequencing-ready library by tagging the samples with Illumina sequences during ligation, RT, and PCR. Libraries were quantified by Qubit and TapeStation as well as by qPCR for actb gene as previously described (Jaitin et alı, 2014; Keren-Shaul et al., 2019). Sequencing was done on a Hiseq 2500 SR50 cycles kit (Illumina).

The data were analyzed using the Pipeline Pilot-designed pipeline for transSeq (by INCPM, https://incpmpm.atlassian.net/wiki/spaces/PUB/pages/36405284/tranSeq+on+Pipeline-Pilot). Briefly, the analysis included adapter trimming, mapping to the $\mathrm{mm} 9$ genome, collapsing of reads with the same unique molecular identifiers (UMI) of 4 bases (R2) and counting of the number of reads per gene with HTseq-count (Anders et al., 2015), using the most 3' 1000 bp of each RefSeq transcript. DESeq2 (version 1.4.5, Love et al., 2014) was used for normalization and differential expression analysis with betaPrior set to true, cooksCutoff=FALSE, independentFiltering=FALSE. BenjaminiHochberg method was used to adjust the raw p-values for multiple testing. Genes with adjusted $p$-value $\leq 0.05$ and fold change $\geq 2$ between every two conditions were considered as differential. PCA analysis was done using log-transformed normalized data (DESeq2 function rlogTransformation with parameter blind=TRUE) with a modified plotPCA function of DESeq2. Clustering of the log-normalized read count of differentially expressed genes was done using CLICK algorithm (Expander package version 7.1, Ulitsky et al., 2010), followed by visualization by $\mathrm{R}$ ( $R$ Development Core Team, 2013). Further analysis was performed using GSEA (Broad institute) and Gorilla (Eden et al., 2009; Subramanian et alı, 2005). The crude data of the work has been deposited on NCBI GEO (GSE144306).

\section{Single-cell library preparation using chromium 10x genomics platform}

Cells were counted and diluted to a final concentration in PBS supplemented with $0.04 \%$ BSA. Cellular suspension was loaded onto Next GEM Chip G targeting 4000 cells and then ran on a Chromium Controller instrument to generate GEM emulsion (10x Genomics). Single-cell 3' RNA-seq libraries were generated according to the manufacturer's protocol (10x Genomics Chromium Single Cell 3' Reagent Kit User Guide v3/v3.1 Chemistry).

\section{Next-generation sequencing of single-cell libraries}

Single-cell 3' RNA-seq libraries were quantified using NEBNext Library Quant Kit for Illumina (NEB) and high sensitivity D1000 TapeStation (Agilent). Libraries were pooled according to targeted cell number, aiming for $\sim 50,000,000$ reads per cell. Pooled libraries were sequenced on a NovaSeq 6000 instrument using an SP 100 cycles reagent kit (Illumina) (R1 28 bases, R2 82 bases, and I1 eight bases), specifically $290 \mathrm{M}$ fragments of the relevant library were sequenced.

\section{scRNA-seq bioinformatic analysis}

Demultiplexing and alignment were performed using cellranger (10x Genomics version 3.0.2) bioinformatics pipeline using mm10 genome, followed by detecting swapped barcodes between libraries, since the NovaSeq run contained a mix of three libraries. For this, we used R (3.6.3) and the package DropletUtiles (Lun et al., 2019) (1.6.1) with the function swappedDrops (parameter min.frac $=0.9$ ) and the molecule_info.h5 input. 1.5\% of the molecules were detected as swapped. Detecting empty droplets was done with the function emptyDrops (parameter lower $=300$ ), the number of cells detected was 2213 .

For additional analysis, the R package Seurat (3.1.5) was used (Butler et al., 2018). The analysis included filtering genes (must be expressed in at least three cells), filtering cells with over 20\% expression of mitochondria genes and high and low 3\% percentiles of total number of genes and 
UMls; this resulted in 1218 cells. In addition, one of the clusters had significantly lower RNA counts as compare to other collected cells, which might have indicated that it contained mainly low-quality cells. Indeed, examination of the 10 most highly expressed genes using heatmap demonstrated this; therefore, this cluster was removed from further analysis. A total of 1076 cells were clustered using 2000 variable genes and 15 principal components $(P C s)$ (resolution $=0.4$ ). UMAP plot was made with the Seurat functions RunUMAP and DimPlot and violin plots were made with the VpnPlot function. The crude data of the work have been deposited on NCBI GEO (GSE160090).

\section{Assay for transposase-accessible chromatin with high-throughput sequencing}

ATAC-seq data were trimmed from their adaptors and filtered from low quality reads using Cutadapt followed by alignment to the mm10 genome (GRCm38.p5) using Bowtie2 (version 2.3.4.1) (Langdon, 2015). PCR-duplicate reads were removed with Picard 'MarkDuplicates' (http://broadinstitute.github.io/picard/). Mitochondrial reads were removed from the alignment, and the data were further filtered to contain only reads with a unique mapping with SAMtools (-F $4 \mathrm{f} 0 \times 2$ ). Read pairs with inner distance of up to $120 \mathrm{bp}$ were selected as representing the accessible chromatin region. MACS2 (version 2.1.1.20160309) (Zhang et al., 2008) was applied for peak calling using the setting: callpeak -f BAMPE-nomodel. Peaks from all samples were combined and merged with BEDTools (Quinlan, 2014), followed by extension to a minimum length of $500 \mathrm{bp}$. For every tissue, a set of reproducible peaks was obtained by voting, which means that a normalized read count $\geq 30$ was detected in at least $50 \%$ of the replicates. Peaks that were not reproducible in any tissue were removed. Peaks that reside in the ENCODE 'Blacklist' regions, that is regions that were previously found by ENCODE (ENCODE Project Consortium, 2012) to produce artificial signal (http://mitra. stanford.edu/kundaje/akundaje/release/blacklists/), were also eliminated. Peak quantification was done with BedTools Quinlan, 2014 following by DESeq2 (Love et al., 2014) normalization. Peaks with an averaged normalized read count $\geq 30$ in at least one of the studied tissues were selected for the downstream analyses. The crude data of the work have been deposited on NCBI GEO (GSE144306).

\section{Annotation and genomic feature enrichment analysis}

Annotation of ATAC-seq peaks was performed using HOMER (Heinz et al., 2010) and GREAT (McLean et al., 2010). When a peak was associated by GREAT to multiple genes, the two closest genes were selected for further analysis. ATAC-seq peaks that were at a distance of up to $-2 \mathrm{~kb}$ down or $+0.5 \mathrm{~kb}$ up from a TSS of their annotated gene (HOMER) were considered as promoter peaks; otherwise, peaks were considered as distal. To rank distal ATAC-seq peaks as putative cisregulatory elements, we calculated the overlap between the peaks and relevant histone modification datasets (ChIP-seq) performed by the ENCODE project (Yue et al., 2014) on E13.5 C57BL/6 mouse embryo limb. The overlap was calculated using BEDTools intersect (Quinlan, 2014). The following datasets were used: ENCSR905FFU (H3K27ac) and ENCSR426EZM (H3K4me1) as markers of enhancers, ENCSR416OYH (H3K4me3) as a marker of promoters and ENCSR022DED (H3K9me3). Overlap with the phastConsElements60wayPlacental track downloaded from the UCSC site (Casper et al., 2018) was calculated to account for evolutionary conservation. Enrichment analysis of over-representation of TFBSs in the ATAC-seq peaks was performed with the RegionMiner tool of Genomatix and HOMER.

\section{Enhancer reporter assays in mouse embryos}

Candidate enhancers were PCR-amplified and cloned upstream of a Shh-promoter-LacZ-reporter cassette. We used a mouse enhancer-reporter assay that relies on site-specific integration of a transgene into the mouse genome (Kvon et al., 2020). In this assay, the reporter cassette is flanked by homology arms targeting the safe harbor locus (Tasic et al., 2011). Cas9 protein and a sgRNA targeting $\mathrm{H} 11$ were co-injected into the pronucleus of FVB single cell-stage mouse embryos (E0.5) together with the reporter vector (Kvon et al., 2020). Embryos were sampled and stained at E14.5. Embryos were excluded from further analysis if they did not carry the reporter transgene. All mouse works were reviewed and approved by the Lawrence Berkeley National Laboratory Animal Welfare and Research Committee. 


\section{Acknowledgements}

We thank Nitzan Konstantin for expert editorial assistance, Dr. Douglas Lutz and service engineer Tal Alon (Getter Bio-Med, Zeiss) for LCM calibration, Neria Sharabi from the Department of Veterinary Resources, Weizmann Institute, and all Zelzer lab members for suggestions and advice. We thank Drs. Merav Kedmi, David Pilzer and Hadas Keren-Shaul from the Genomics Sandbox unit at the Life Science Core Facility, Weizmann Institute of Science, for critical advice. We thank E Sebzda for providing floxed Klf2 mice and the Mutant Mouse Regional Resource Center (MMRRC) at UC Davis for providing floxed Klf4 mice. We thank the ENCODE Consortium and the ENCODE production laboratory for generating the described datasets. This study was supported by grants from the Israel Science Foundation (ISF, grant No. 345/16), National Institute of Health (grant No. R01 AR055580), Minerva Foundation (grant No. 713533), the Estate of Mr. and Mrs. van Adelsbergen, and the David and Fela Shapell Family Center for Genetic Disorders (to EZ). Work at Lawrence Berkeley National Lab was supported by National Institute of Health grant R01HG003988 (to AV) and performed under Department of Energy Contract DE-AC02-05CH11231, University of California. MO was supported by Swiss National Science Foundation grant PCEFP3_186993.

\section{Additional information}

Funding

\begin{tabular}{lll} 
Funder & Grant reference number & Author \\
\hline National Institutes of Health & R01 AR055580 & Elazar Zelzer \\
\hline National Institutes of Health & R01HG003988 & Axel Visel \\
\hline Israel Science Foundation & grant No. 345/16 & Elazar Zelzer \\
\hline Minerva Foundation & grant No. 713533 & Elazar Zelzer \\
\hline $\begin{array}{l}\text { David and Fela Shapell Family } \\
\text { Center for Genetic Disorders }\end{array}$ & & Elazar Zelzer \\
\hline $\begin{array}{l}\text { Estate of Mr. and Mrs. van } \\
\text { Adelsberge }\end{array}$ & & Elazar Zelzer \\
\hline $\begin{array}{l}\text { University of California } \\
\begin{array}{l}\text { Swiss National Science Foun- } \\
\text { dation }\end{array}\end{array}$ & PCEFP3_186993 & Marco Osterwalder \\
\hline
\end{tabular}

The funders had no role in study design, data collection and interpretation, or the decision to submit the work for publication.

Author contributions

Shiri Kult, Conceptualization, Validation, Investigation, Visualization, Methodology, Writing - original draft; Tsviya Olender, Dena Leshkowitz, Data curation, Software, Formal analysis, Validation, Visualization, Methodology, Writing - review and editing; Marco Osterwalder, Validation, Investigation, Visualization, Methodology, Writing - review and editing; Svetalana Markman, Visualization, Writing review and editing; Sharon Krief, Validation, Investigation, Visualization, Methodology; Ronnie Blecher-Gonen, Investigation, Methodology; Shani Ben-Moshe, Investigation, Visualization, Methodology, Writing - review and editing; Lydia Farack, Software, Methodology, Writing - review and editing; Hadas Keren-Shaul, Investigation, Methodology, Writing - review and editing; Tomer-Meir Salame, Data curation, Formal analysis, Validation, Methodology, Writing - review and editing; Terence D Capellini, Resources, Writing - review and editing; Shalev Itzkovitz, Resources, Methodology, Writing - review and editing; Ido Amit, Resources, Methodology; Axel Visel, Resources, Funding acquisition, Methodology, Writing - review and editing; Elazar Zelzer, Conceptualization, Supervision, Funding acquisition, Methodology, Writing - original draft, Project administration

Author ORCIDs

Shiri Kult (iD http://orcid.org/0000-0001-8216-2908

Marco Osterwalder (iD http://orcid.org/0000-0002-1969-2313 
Lydia Farack (iD) http://orcid.org/0000-0001-9597-5078

Terence D Capellini (iD) http://orcid.org/0000-0003-3842-8478

Shalev Itzkovitz (D) http://orcid.org/0000-0003-0685-2522

Axel Visel (iD) http://orcid.org/0000-0002-4130-7784

Elazar Zelzer (iD) https://orcid.org/0000-0002-1584-6602

Ethics

Animal experimentation: All mice were maintained and used in accordance with protocols approved by the Weizmann Institutional Animal Care and Use Committee (IACUC; permission no. 105501192). All animal work was reviewed and approved by the Lawrence Berkeley National Laboratory (LBNL) Animal Welfare Committee. All mice used in this study were housed at the Animal Care Facility (ACF) at LBNL. Mice were monitored daily for food and water intake, and animals were inspected weekly by the Chair of the Animal Welfare and Research Committee and the head of the animal facility in consultation with the veterinary staff. The LBNL ACF is accredited by the American Association for the Accreditation of Laboratory Animal Care (AAALAC). Transgenic mouse assays were performed in Mus musculus FVB background mice.

Decision letter and Author response

Decision letter https://doi.org/10.7554/eLife.55361.sa1

Author response https://doi.org/10.7554/eLife.55361.sa2

\section{Additional files}

Supplementary files

- Supplementary file 1. Hierarchical clustering of bulk MARS-seq data from E14.5 attachment site samples. Ordered genes and samples were combined by complete-linkage clustering using the similarity measurement of Pearson correlation. A, remote tenocytes; B, adjacent tenocytes; $C$, remote chondrocytes; D, adjacent chondrocytes; E, attachment cells.

- Supplementary file 2. List of probes used for single-molecule fluorescent in situ hybridization for biglycan (Bgn) and Wwp2.

- Supplementary file 3. List of intergenic regions (non-TSS). The peaks were selected based on their enhanced ATAC-seq signal (cutoff of averaged ATAC-seq signal > 30.0) and their association with differentially expressed genes. 'Attachment specific' sheet lists 248 peaks that are accessible only in attachment cells. The table includes transcription factors such as Klf4, Runx3, and Nfia, in addition to ECM-associated genes such as Col11a1 and Bgn.

- Transparent reporting form

Data availability

The data was submitted to GEO (GSE144306). Additional data of scRNA-seq was submitted to GEO (GSE160090).

The following datasets were generated:

\begin{tabular}{|c|c|c|c|c|}
\hline Author(s) & Year & Dataset title & Dataset URL & Database and Identifier \\
\hline $\begin{array}{l}\text { Kult S, Olender T, } \\
\text { Osterwalder M, } \\
\text { Markman S, } \\
\text { Leshkowitz D, Krief } \\
\text { S, Blecher-Gonen } \\
\text { R, Ben-Moshe S, } \\
\text { Farack L, Keren- } \\
\text { Shaul H, } \\
\text { Meir Salame T, } \\
\text { Capellini TD, } \\
\text { Itzkovitz S, Amit I, } \\
\text { Visel A, Zelzer E }\end{array}$ & 2020 & $\begin{array}{l}\text { Bi-fated tendon-to-bone } \\
\text { attachment cells are regulated } \\
\text { by shared enhancers and KLF } \\
\text { transcription factors }\end{array}$ & $\begin{array}{l}\text { https://www.ncbi.nlm. } \\
\text { nih.gov/geo/query/acc. } \\
\text { cgi?acc=GSE144306 }\end{array}$ & $\begin{array}{l}\text { NCBI Gene Expression } \\
\text { Omnibus, GSE144306 }\end{array}$ \\
\hline
\end{tabular}


Kult $\mathrm{S}$, Olender $\mathrm{T}$, Osterwalder M Markman S, Leshkowitz D, Krief

$\mathrm{S}$, Blecher-Gonen

$\mathrm{R}$, Ben-Moshe $\mathrm{S}$,

Farack L, Keren-

Shaul $\mathrm{H}_{\text {, }}$

Meir Salame T,

Capellini TD

Itzkovitz S, Amit I,

Visel A, Zelzer E https://www.ncbi.nlm. attachment cells are regulated nih.gov/geo/query/acc. by shared enhancers and KLF cgi?acc $=$ GSE160090 transcription factors
NCBI Gene Expression Omnibus, GSE160090

The following previously published datasets were used:

\begin{tabular}{|c|c|c|c|c|}
\hline Author(s) & Year & Dataset title & Dataset URL & $\begin{array}{l}\text { Database and } \\
\text { Identifier }\end{array}$ \\
\hline Ren B, UCSD & 2015 & $\begin{array}{l}\text { H3K27ac ChIP-seq on embryonic } \\
13.5 \text { day mouse limb }\end{array}$ & $\begin{array}{l}\text { https://www.encodepro- } \\
\text { ject.org/experiments/ } \\
\text { ENCSR905FFU/ }\end{array}$ & $\begin{array}{l}\text { ENCODE, ENCSR90 } \\
\text { 5FFU }\end{array}$ \\
\hline Ren B, UCSD & 2015 & $\begin{array}{l}\text { H3K4me1 ChIP-seq on embryonic } \\
13.5 \text { day mouse limb }\end{array}$ & $\begin{array}{l}\text { https://www.encodepro- } \\
\text { ject.org/experiments/ } \\
\text { ENCSR426EZM/ }\end{array}$ & $\begin{array}{l}\text { ENCODE, } \\
\text { ENCSR426EZM }\end{array}$ \\
\hline Ren B, UCSD & 2015 & $\begin{array}{l}\text { H3K4me3 ChIP-seq on embryonic } \\
13.5 \text { day mouse limb }\end{array}$ & $\begin{array}{l}\text { https://www.encodepro- } \\
\text { ject.org/experiments/ } \\
\text { ENCSR416OYH/ }\end{array}$ & $\begin{array}{l}\text { ENCODE, } \\
\text { ENCSR416OYH }\end{array}$ \\
\hline Ren B, UCSD & 2015 & $\begin{array}{l}\text { H3K9me3 ChIP-seq on embryonic } \\
13.5 \text { day mouse limb }\end{array}$ & $\begin{array}{l}\text { https://www.encodepro- } \\
\text { ject.org/experiments/ } \\
\text { ENCSR022DED/ }\end{array}$ & $\begin{array}{l}\text { ENCODE， ENCSRO } \\
\text { 22DED }\end{array}$ \\
\hline
\end{tabular}

\section{References}

Aldiri I, Xu B, Wang L, Chen X, Hiler D, Griffiths L, Valentine M, Shirinifard A, Thiagarajan S, Sablauer A, Barabas M-E, Zhang J, Johnson D, Frase S, Zhou X, Easton J, Zhang J, Mardis ER, Wilson RK, Downing JR, et al. 2017. The dynamic epigenetic landscape of the retina during development, reprogramming, and tumorigenesis. Neuron 94:550-568. DOl: https://doi.org/10.1016/j.neuron.2017.04.022

Anders S, Pyl PT, Huber W. 2015. HTSeq-a Python framework to work with high-throughput sequencing data. Bioinformatics 31:166-169. DOI: https://doi.org/10.1093/bioinformatics/btu638, PMID: 25260700

Andrey G, Schöpflin R, Jerković I, Heinrich V, Ibrahim DM, Paliou C, Hochradel M, Timmermann B, Haas S, Vingron M, Mundlos S. 2017. Characterization of hundreds of regulatory landscapes in developing limbs reveals two regimes of chromatin folding. Genome Research 27:223-233. DOI: https://doi.org/10.1101/gr. 213066.116

Barone LM, Owen TA, Tassinari MS, Bortell R, Stein GS, Lian JB. 1991. Developmental expression and hormonal regulation of the rat matrix gla protein (MGP) gene in chondrogenesis and osteogenesis. Journal of Cellular Biochemistry 46:351-365. DOI: https://doi.org/10.1002/jcb.240460410, PMID: 1757478

Bergers G, Song S. 2005. The role of pericytes in blood-vessel formation and maintenance. Neuro-Oncology 7: 452-464. DOI: https://doi.org/10.1215/S1152851705000232, PMID: 16212810

Bhattacherjee V, Mukhopadhyay P, Singh S, Roberts EA, Hackmiller RC, Greene RM, Pisano MM. 2004. Laser capture microdissection of fluorescently labeled embryonic cranial neural crest cells. Genesis 39:58-64. DOI: https://doi.org/10.1002/gene.20026, PMID: 15124228

Blitz E, Viukov S, Sharir A, Shwartz Y, Galloway JL, Pryce BA, Johnson RL, Tabin CJ, Schweitzer R, Zelzer E. 2009. Bone ridge patterning during musculoskeletal assembly is mediated through SCX regulation of Bmp4 at the Tendon-Skeleton junction. Developmental Cell 17:861-873. DOI: https://doi.org/10.1016/j.devcel.2009.10.010

Blitz E, Sharir A, Akiyama H, Zelzer E. 2013. Tendon-bone attachment unit is formed modularly by a distinct pool of scx- and Sox9-positive progenitors. Development 140:2680-2690. DOI: https://doi.org/10.1242/dev.093906, PMID: 23720048

Buenrostro JD, Wu B, Chang HY, Greenleaf WJ. 2015. ATAC-seq: a method for assaying chromatin accessibility Genome-Wide. Current Protocols in Molecular Biology 109:21-29. DOI: https://doi.org/10.1002/0471142727. mb2129s109, PMID: 25559105

Butler A, Hoffman P, Smibert P, Papalexi E, Satija R. 2018. Integrating single-cell transcriptomic data across different conditions, technologies, and species. Nature Biotechnology 36:411-420. DOI: https://doi.org/10. 1038/nbt.4096, PMID: 29608179

Casper J, Zweig AS, Villarreal C, Tyner C, Speir ML, Rosenbloom KR, Raney BJ, Lee CM, Lee BT, Karolchik D, Hinrichs AS, Haeussler M, Guruvadoo L, Navarro Gonzalez J, Gibson D, Fiddes IT, Eisenhart C, Diekhans M, Clawson H, Barber GP, et al. 2018. The UCSC genome browser database: 2018 update. Nucleic Acids Research 46:D762-D769. DOI: https://doi.org/10.1093/nar/gkx1020 
Chawengsaksophak K. 2019. Cdx2 animal models reveal developmental origins of cancers. Genes 10:928. DOI: https://doi.org/10.3390/genes10110928

Chiplunkar AR, Curtis BC, Eades GL, Kane MS, Fox SJ, Haar JL, Lloyd JA. 2013. The Krüppel-like factor 2 and Krüppel-like factor 4 genes interact to maintain endothelial integrity in mouse embryonic vasculogenesis. $B M C$ Developmental Biology 13:40. DOI: https://doi.org/10.1186/1471-213X-13-40, PMID: 24261709

Dang DT, Pevsner J, Yang VW. 2000. The biology of the mammalian Krüppel-like family of transcription factors. The International Journal of Biochemistry \& Cell Biology 32:1103-1121. DOI: https://doi.org/10.1016/S13572725(00)00059-5, PMID: 11137451

Deimling SJ, Lau K, Hui CC, Hopyan S. 2018. Genetic interaction between Gli3 and Ezh2 during limb pattern formation. Mechanisms of Development 151:30-36. DOI: https://doi.org/10.1016/j.mod.2018.05.002, PMID: 2 9729398

Dekker RJ, van Thienen JV , Rohlena J, de Jager SC, Elderkamp YW, Seppen J, de Vries CJ, Biessen EA, van Berkel TJ, Pannekoek H, Horrevoets AJ. 2005. Endothelial KLF2 links local arterial shear stress levels to the expression of vascular tone-regulating genes. The American Journal of Pathology 167:609-618. DOI: https:// doi.org/10.1016/S0002-9440(10)63002-7

Dyment NA, Breidenbach AP, Schwartz AG, Russell RP, Aschbacher-Smith L, Liu H, Hagiwara Y, Jiang R, Thomopoulos S, Butler DL, Rowe DW. 2015. Gdf5 progenitors give rise to fibrocartilage cells that mineralize via hedgehog signaling to form the zonal enthesis. Developmental Biology 405:96-107. DOI: https://doi.org/10. 1016/j.ydbio.2015.06.020, PMID: 26141957

Eden E, Navon R, Steinfeld I, Lipson D, Yakhini Z. 2009. GOrilla: a tool for discovery and visualization of enriched GO terms in ranked gene lists. BMC Bioinformatics 10:48. DOI: https://doi.org/10.1186/1471-2105-10-48, PMID: 19192299

ENCODE Project Consortium. 2012. An integrated encyclopedia of DNA elements in the human genome. Nature 489:57-74. DOI: https://doi.org/10.1038/nature11247, PMID: 22955616

Eyal S, Kult S, Rubin S, Krief S, Felsenthal N, Pineault KM, Leshkowitz D, Salame TM, Addadi Y, Wellik DM, Zelzer E. 2019. Bone morphology is regulated modularly by global and regional genetic programs. Development 146: dev167882. DOI: https://doi.org/10.1242/dev.167882, PMID: 31221640

Felsenthal N, Rubin S, Stern T, Krief S, Pal D, Pryce BA, Schweitzer R, Zelzer E. 2018. Development of migrating tendon-bone attachments involves replacement of progenitor populations. Development 145:dev165381. DOI: https://doi.org/10.1242/dev.165381, PMID: 30504126

Galatz LM, Ball CM, Teefey SA, Middleton WD, Yamaguchi K. 2004. The outcome and repair integrity of completely arthroscopically repaired large and massive rotator cuff tears. The Journal of Bone \& Joint Surgery 86:219-224. DOI: https://doi.org/10.2106/00004623-200402000-00002, PMID: 14960664

Genin GM, Kent A, Birman V, Wopenka B, Pasteris JD, Marquez PJ, Thomopoulos S. 2009. Functional grading of mineral and collagen in the attachment of tendon to bone. Biophysical Journal 97:976-985. DOI: https://doi. org/10.1016/j.bpj.2009.05.043, PMID: 19686644

Guo M, Liu Z, Willen J, Shaw CP, Richard D, Jagoda E, Doxey AC, Hirschhorn J, Capellini TD. 2017. Epigenetic profiling of growth plate chondrocytes sheds insight into regulatory genetic variation influencing height. eLife 6:e29329. DOI: https://doi.org/10.7554/eLife.29329, PMID: 29205154

Harryman DT, Mack LA, Wang KY, Jackins SE, Richardson ML, Matsen FA. 1991. Repairs of the rotator cuff. Correlation of functional results with integrity of the cuff. The Journal of Bone \& Joint Surgery 73:982-989. DOI: https://doi.org/10.2106/00004623-199173070-00004

Heinz S, Benner C, Spann N, Bertolino E, Lin YC, Laslo P, Cheng JX, Murre C, Singh H, Glass CK. 2010. Simple combinations of lineage-determining transcription factors prime cis-regulatory elements required for macrophage and B cell identities. Molecular Cell 38:576-589. DOI: https://doi.org/10.1016/j.molcel.2010.05 004, PMID: 20513432

Hu G, Schones DE, Cui K, Ybarra R, Northrup D, Tang Q, Gattinoni L, Restifo NP, Huang S, Zhao K. 2011. Regulation of nucleosome landscape and transcription factor targeting at tissue-specific enhancers by BRG1. Genome Research 21:1650-1658. DOl: https://doi.org/10.1101/gr.121145.111

Itzkovitz S, Lyubimova A, Blat IC, Maynard M, van Es J, Lees J, Jacks T, Clevers H, van Oudenaarden A. 2012. Single-molecule transcript counting of stem-cell markers in the mouse intestine. Nature Cell Biology 14:106114. DOI: https://doi.org/10.1038/ncb2384

Jaitin DA, Kenigsberg E, Keren-Shaul H, Elefant N, Paul F, Zaretsky I, Mildner A, Cohen N, Jung S, Tanay A, Amit I. 2014. Massively parallel single-cell RNA-seq for marker-free decomposition of tissues into cell types. Science 343:776-779. DOl: https://doi.org/10.1126/science.1247651, PMID: 24531970

Jiang J, Chan YS, Loh YH, Cai J, Tong GQ, Lim CA, Robson P, Zhong S, Ng HH. 2008. A core klf circuitry regulates self-renewal of embryonic stem cells. Nature Cell Biology 10:353-360. DOI: https://doi.org/10.1038/ ncb1698, PMID: 18264089

Johnson MB, Wang PP, Atabay KD, Murphy EA, Doan RN, Hecht JL, Walsh CA. 2015. Single-cell analysis reveals transcriptional heterogeneity of neural progenitors in human cortex. Nature Neuroscience 18:637-646. DOI: https://doi.org/10.1038/nn.3980, PMID: 25734491

Johnson RL, Tabin CJ. 1997. Molecular models for vertebrate limb development. Cell 90:979-990. DOI: https:// doi.org/10.1016/S0092-8674(00)80364-5, PMID: 9323126

Katz JP, Perreault N, Goldstein BG, Lee CS, Labosky PA, Yang VW, Kaestner KH. 2002. The zinc-finger transcription factor Klf4 is required for terminal differentiation of goblet cells in the Colon. Development 129: 2619-2628. PMID: 12015290 
Keren-Shaul H, Kenigsberg E, Jaitin DA, David E, Paul F, Tanay A, Amit I. 2019. MARS-seq2.0: an experimental and analytical pipeline for indexed sorting combined with single-cell RNA sequencing. Nature Protocols 14: 1841-1862. DOI: https://doi.org/10.1038/s41596-019-0164-4, PMID: 31101904

Kuo CT, Veselits ML, Leiden JM. 1997. LKLF: a transcriptional regulator of single-positive T cell quiescence and survival. Science 277:1986-1990. DOI: https://doi.org/10.1126/science.277.5334.1986, PMID: 9302292

Kvon EZ, Zhu Y, Kelman G, Novak CS, Plajzer-Frick I, Kato M, Garvin TH, Pham Q, Harrington AN, Hunter RD, Godoy J, Meky EM, Akiyama JA, Afzal V, Tran S, Escande F, Gilbert-Dussardier B, Jean-Marçais N, Hudaiberdiev S, Ovcharenko I, et al. 2020. Comprehensive in Vivo Interrogation Reveals Phenotypic Impact of Human Enhancer Variants. Cell 180:1262-1271. DOI: https://doi.org/10.1016/j.cell.2020.02.031, PMID: 3216 9219

Langdon WB. 2015. Performance of genetic programming optimised Bowtie2 on genome comparison and analytic testing (GCAT) benchmarks. BioData Mining 8:1. DOl: https://doi.org/10.1186/s13040-014-0034-0, PMID: 25621011

Laugesen A, Helin K. 2014. Chromatin repressive complexes in stem cells, development, and Cancer. Cell Stem Cell 14:735-751. DOI: https://doi.org/10.1016/j.stem.2014.05.006, PMID: 24905164

Lee JS, Yu Q, Shin JT, Sebzda E, Bertozzi C, Chen M, Mericko P, Stadtfeld M, Zhou D, Cheng L, Graf T, MacRae CA, Lepore JJ, Lo CW, Kahn ML. 2006. KIf2 is an essential regulator of vascular hemodynamic forces in vivo. Developmental Cell 11:845-857. DOI: https://doi.org/10.1016/j.devcel.2006.09.006, PMID: 17141159

Lehman C, Cuomo F, Kummer FJ, Zuckerman JD. 1995. The incidence of full thickness rotator cuff tears in a large cadaveric population. Bulletin (Hospital for Joint Diseases 54:30-31. PMID: 8541777

Li Y, Lacerda DA, Warman ML, Beier DR, Yoshioka H, Ninomiya Y, Oxford JT, Morris NP, Andrikopoulos K, Ramirez F. 1995. A fibrillar collagen gene, Col11a1, is essential for skeletal morphogenesis. Cell 80:423-430. DOI: https://doi.org/10.1016/0092-8674(95)90492-1, PMID: 7859283

Liu S, Li J, Tan DT, Beuerman RW. 2007. The eyelid margin: a transitional zone for 2 epithelial phenotypes. Archives of Ophthalmology 125:523-532. DOI: https://doi.org/10.1001/archopht.125.4.523, PMID: 17420373

Liu Y, Birman V, Chen C, Thomopoulos S, Genin GM. 2011. Mechanisms of bimaterial attachment at the interface of tendon to bone. Journal of Engineering Materials and Technology 133:e011006. DOI: https://doi.org/10. $1115 / 1.4002641$

Liu YX, Thomopoulos S, Birman V, Li J-S, Genin GM. 2012a. Bi-material attachment through a compliant interfacial system at the tendon-to-bone insertion site. Mechanics of Materials 44:83-92. DOI: https://doi.org/ 10.1016/j.mechmat.2011.08.005

Liu CF, Aschbacher-Smith L, Barthelery NJ, Dyment N, Butler D, Wylie C. 2012b. Spatial and temporal expression of molecular markers and cell signals during normal development of the mouse patellar tendon. Tissue Engineering Part A 18:598-608. DOI: https://doi.org/10.1089/ten.tea.2011.0338, PMID: 21939397

Liu CF, Breidenbach A, Aschbacher-Smith L, Butler D, Wylie C. 2013. A role for hedgehog signaling in the differentiation of the insertion site of the patellar tendon in the mouse. PLOS ONE 8:e65411. DOI: https://doi. org/10.1371/journal.pone.0065411, PMID: 23762363

Liu ES, Martins JS, Zhang W, Demay MB. 2018. Molecular analysis of enthesopathy in a mouse model of hypophosphatemic rickets. Development 145:dev163519. DOI: https://doi.org/10.1242/dev.163519, PMID: 30002128

Logan M, Martin JF, Nagy A, Lobe C, Olson EN, Tabin CJ. 2002. Expression of cre recombinase in the developing mouse limb bud driven by a prxl enhancer. Genesis 33:77-80. DOI: https://doi.org/10.1002/gene. 10092, PMID: 12112875

Love MI, Huber W, Anders S. 2014. Moderated estimation of fold change and dispersion for RNA-seq data with DESeq2. Genome Biology 15:550. DOI: https://doi.org/10.1186/s13059-014-0550-8, PMID: 25516281

Lu HH, Thomopoulos S. 2013. Functional attachment of soft tissues to bone: development, healing, and tissue engineering. Annual Review of Biomedical Engineering 15:201-226. DOI: https://doi.org/10.1146/annurevbioeng-071910-124656, PMID: 23642244

Lun ATL, Riesenfeld S, Andrews T, Dao TP, Gomes T, Marioni JC, participants in the 1st Human Cell Atlas Jamboree. 2019. EmptyDrops: distinguishing cells from empty droplets in droplet-based single-cell RNA sequencing data. Genome Biology 20:63. DOI: https://doi.org/10.1186/s13059-019-1662-y, PMID: 30902100

Lyubimova A, Itzkovitz S, Junker JP, Fan ZP, Wu X, van Oudenaarden A. 2013. Single-molecule mRNA detection and counting in mammalian tissue. Nature Protocols 8:1743-1758. DOI: https://doi.org/10.1038/nprot.2013. 109, PMID: 23949380

Madisen L, Zwingman TA, Sunkin SM, Oh SW, Zariwala HA, Gu H, Ng LL, Palmiter RD, Hawrylycz MJ, Jones AR, Lein ES, Zeng H. 2010. A robust and high-throughput cre reporting and characterization system for the whole mouse brain. Nature Neuroscience 13:133-140. DOI: https://doi.org/10.1038/nn.2467, PMID: 20023653

McDonald SA, Lavery D, Wright NA, Jansen M. 2015. Barrett oesophagus: lessons on its origins from the lesion itself. Nature Reviews Gastroenterology \& Hepatology 12:50-60. DOI: https://doi.org/10.1038/nrgastro.2014. 181, PMID: 25365976

McLean CY, Bristor D, Hiller M, Clarke SL, Schaar BT, Lowe CB, Wenger AM, Bejerano G. 2010. GREAT improves functional interpretation of cis-regulatory regions. Nature Biotechnology 28:495-501. DOI: https://doi.org/10. 1038/nbt.1630, PMID: 20436461

Michikami I, Fukushi T, Tanaka M, Egusa H, Maeda Y, Ooshima T, Wakisaka S, Abe M. 2012. Krüppel-like factor 4 regulates membranous and endochondral ossification. Experimental Cell Research 318:311-325.

DOI: https://doi.org/10.1016/j.yexcr.2011.12.013, PMID: 22206865 
Nakamura E, Nguyen MT, Mackem S. 2006. Kinetics of tamoxifen-regulated cre activity in mice using a cartilagespecific CreER(T) to assay temporal activity windows along the proximodistal limb skeleton. Developmental Dynamics 235:2603-2612. DOI: https://doi.org/10.1002/dvdy.20892, PMID: 16894608

Orgeur M, Martens M, Leonte G, Nassari S, Bonnin MA, Börno ST, Timmermann B, Hecht J, Duprez D, Stricker S. 2018. Genome-wide strategies identify downstream target genes of chick connective tissue-associated transcription factors. Development 145:dev161208. DOI: https://doi.org/10.1242/dev.161208, PMID: 29511024

Ovchinnikov DA, Deng JM, Ogunrinu G, Behringer RR. 2000. Col2a1-directed expression of cre recombinase in differentiating chondrocytes in transgenic mice. Genesis 26:145-146. DOI: https://doi.org/10.1002/(SICI)1526968X(200002)26:2<145::AID-GENE14>3.0.CO;2-C, PMID: 10686612

Pazin DE, Gamer LW, Cox KA, Rosen V. 2012. Molecular profiling of synovial joints: use of microarray analysis to identify factors that direct the development of the knee and elbow. Developmental Dynamics 241:1816-1826. DOI: https://doi.org/10.1002/dvdy.23861, PMID: 22972626

Pryce BA, Brent AE, Murchison ND, Tabin CJ, Schweitzer R. 2007. Generation of transgenic tendon reporters, ScxGFP and ScxAP, using regulatory elements of the scleraxis gene. Developmental Dynamics 236:1677-1682. DOI: https://doi.org/10.1002/dvdy.21179, PMID: 17497702

Quinlan AR. 2014. BEDTools: the Swiss-Army tool for genome feature analysis. Current Protocols in

Bioinformatics 47:11-34. DOI: https://doi.org/10.1002/0471250953.bi1112s47, PMID: 25199790

R Development Core Team. 2013. R: A language and environment for statistical computing. Vienna, Austria, R Foundation for Statistical Computing. http://www.R-project.org

Raj A, van den Bogaard P, Rifkin SA, van Oudenaarden A, Tyagi S. 2008. Imaging individual mRNA molecules using multiple singly labeled probes. Nature Methods 5:877-879. DOI: https://doi.org/10.1038/nmeth.1253, PMID: 18806792

Riddle RD, Johnson RL, Laufer E, Tabin C. 1993. Sonic hedgehog mediates the polarizing activity of the ZPA. Cell 75:1401-1416. DOI: https://doi.org/10.1016/0092-8674(93)90626-2, PMID: 8269518

Roberts RR, Bobzin L, Teng CS, Pal D, Tuzon CT, Schweitzer R, Merrill AE. 2019. FGF signaling patterns cell fate at the interface between tendon and bone. Development 146:dev170241. DOI: https://doi.org/10.1242/dev. 170241, PMID: 31320326

Romih R, Korosec P, de Mello W, Jezernik K. 2005. Differentiation of epithelial cells in the urinary tract. Cell and Tissue Research 320:259-268. DOI: https://doi.org/10.1007/s00441-004-1005-4, PMID: 15778856

San Roman AK, Shivdasani RA. 2011. Boundaries, junctions and transitions in the gastrointestinal tract. Experimental Cell Research 317:2711-2718. DOI: https://doi.org/10.1016/j.yexcr.2011.07.011, PMID: 21 802415

Schindelin J, Arganda-Carreras I, Frise E, Kaynig V, Longair M, Pietzsch T, Preibisch S, Rueden C, Saalfeld S, Schmid B, Tinevez JY, White DJ, Hartenstein V, Eliceiri K, Tomancak P, Cardona A. 2012. Fiji: an open-source platform for biological-image analysis. Nature Methods 9:676-682. DOI: https://doi.org/10.1038/nmeth.2019, PMID: 22743772

Schwartz AG, Long F, Thomopoulos S. 2015. Enthesis fibrocartilage cells originate from a population of Hedgehog-responsive cells modulated by the loading environment. Development 142:196-206. DOI: https:// doi.org/10.1242/dev.112714, PMID: 25516975

Schwartz AG, Galatz LM, Thomopoulos S. 2017. Enthesis regeneration: a role for Gli1+ progenitor cells. Development 144:1159-1164. DOI: https://doi.org/10.1242/dev.139303, PMID: 28219952

Segre JA, Bauer C, Fuchs E. 1999. KIf4 is a transcription factor required for establishing the barrier function of the skin. Nature Genetics 22:356-360. DOI: https://doi.org/10.1038/11926, PMID: 10431239

Shields JM, Yang VW. 1997. Two potent nuclear localization signals in the Gut-enriched Krüppel-like factor define a subfamily of closely related krüppel proteins. Journal of Biological Chemistry 272:18504-18507. DOI: https://doi.org/10.1074/jbc.272.29.18504

Shwartz Y, Zelzer E. 2014. Nonradioactive in situ hybridization on skeletal tissue sections. Methods in Molecular Biology 1130:203-215. DOI: https://doi.org/10.1007/978-1-62703-989-5_15, PMID: 24482175

Soeda T, Deng JM, de Crombrugghe B, Behringer RR, Nakamura T, Akiyama H. 2010. Sox9-expressing precursors are the cellular origin of the cruciate ligament of the knee joint and the limb tendons. Genesis 48 : 635-644. DOI: https://doi.org/10.1002/dvg.20667, PMID: 20806356

Soldatov R, Kaucka M, Kastriti ME, Petersen J, Chontorotzea T, Englmaier L, Akkuratova N, Yang Y, Häring M, Dyachuk V, Bock C, Farlik M, Piacentino ML, Boismoreau F, Hilscher MM, Yokota C, Qian X, Nilsson M, Bronner ME, Croci L, et al. 2019. Spatiotemporal structure of cell fate decisions in murine neural crest. Science 364: eaas9536. DOI: https://doi.org/10.1126/science.aas9536, PMID: 31171666

Subramanian A, Tamayo P, Mootha VK, Mukherjee S, Ebert BL, Gillette MA, Paulovich A, Pomeroy SL, Golub TR, Lander ES, Mesirov JP. 2005. Gene set enrichment analysis: a knowledge-based approach for interpreting genome-wide expression profiles. PNAS 102:15545-15550. DOl: https://doi.org/10.1073/pnas.0506580102, PMID: 16199517

Sugimoto Y, Takimoto A, Akiyama H, Kist R, Scherer G, Nakamura T, Hiraki Y, Shukunami C. 2013. Scx+/Sox9+ progenitors contribute to the establishment of the junction between cartilage and tendon/ligament. Development 140:2280-2288. DOI: https://doi.org/10.1242/dev.096354

Takahashi K, Yamanaka S. 2006. Induction of Pluripotent Stem Cells from Mouse Embryonic and Adult Fibroblast Cultures by Defined Factors. Cell 126:663-676. DOI: https://doi.org/10.1016/j.cell.2006.07.024

Tasic B, Hippenmeyer S, Wang C, Gamboa M, Zong H, Chen-Tsai Y, Luo L. 2011. Site-specific integrasemediated transgenesis in mice via pronuclear injection. PNAS 108:7902-7907. DOI: https://doi.org/10.1073/ pnas.1019507108, PMID: 21464299 
Thomopoulos S, Williams GR, Gimbel JA, Favata M, Soslowsky LJ. 2003. Variation of biomechanical, structural, and compositional properties along the tendon to bone insertion site. Journal of Orthopaedic Research 21: 413-419. DOI: https://doi.org/10.1016/S0736-0266(03)0057-3, PMID: 12706013

Thomopoulos S, Genin GM, Galatz LM. 2010. The development and morphogenesis of the tendon-to-bone insertion - what development can teach us about healing. Journal of Musculoskeletal \& Neuronal Interactions 10:35-45. PMID: 20190378

Ulitsky I, Maron-Katz A, Shavit S, Sagir D, Linhart C, Elkon R, Tanay A, Sharan R, Shiloh Y, Shamir R. 2010. Expander: from expression microarrays to networks and functions. Nature Protocols 5:303-322. DOI: https:// doi.org/10.1038/nprot.2009.230, PMID: 20134430

Villarreal G, Zhang Y, Larman HB, Gracia-Sancho J, Koo A, García-Cardeña G. 2010. Defining the regulation of KLF4 expression and its downstream transcriptional targets in vascular endothelial cells. Biochemical and Biophysical Research Communications 391:984-989. DOI: https://doi.org/10.1016/j.bbrc.2009.12.002, PMID: 1 9968965

Yue F, Cheng Y, Breschi A, Vierstra J, Wu W, Ryba T, Sandstrom R, Ma Z, Davis C, Pope BD, Shen Y, Pervouchine DD, Djebali S, Thurman RE, Kaul R, Rynes E, Kirilusha A, Marinov GK, Williams BA, Trout D, et al. 2014. A comparative encyclopedia of DNA elements in the mouse genome. Nature 515:355-364. DOI: https://doi.org/ 10.1038/nature13992

Zhang Y, Liu T, Meyer CA, Eeckhoute J, Johnson DS, Bernstein BE, Nussbaum C, Myers RM, Brown M, Li W, Liu XS. 2008. Model-based analysis of ChIP-Seq (MACS). Genome Biology 9:R137. DOI: https://doi.org/10.1186/ gb-2008-9-9-r137

Zhu J, Adli M, Zou JY, Verstappen G, Coyne M, Zhang X, Durham T, Miri M, Deshpande V, De Jager PL, Bennett DA, Houmard JA, Muoio DM, Onder TT, Camahort R, Cowan CA, Meissner A, Epstein CB, Shoresh N, Bernstein BE. 2013. Genome-wide chromatin state transitions associated with developmental and environmental cues. Cell 152:642-654. DOI: https://doi.org/10.1016/j.cell.2012.12.033, PMID: 23333102 


\section{Appendix 1}

Appendix 1-key resources table

\begin{tabular}{|c|c|c|c|c|}
\hline $\begin{array}{l}\text { Reagent } \\
\text { type } \\
\text { (species) or } \\
\text { resource }\end{array}$ & Designation & Source or reference & Identifiers & $\begin{array}{l}\text { Additional } \\
\text { information }\end{array}$ \\
\hline $\begin{array}{l}\text { Strain, strain } \\
\text { background } \\
\text { (Mus } \\
\text { musculus) }\end{array}$ & Sox9-CreER, C57BL/6 & $\begin{array}{l}\text { DOI: } 10.1002 / \mathrm{dvg} . \\
20667\end{array}$ & & FACS \\
\hline $\begin{array}{l}\text { Strain, strain } \\
\text { background } \\
\text { (M. } \\
\text { musculus) }\end{array}$ & R26R-tdTomato, C57BL/6 & DOI:10.1038/nn.2467 & & FACS \\
\hline $\begin{array}{l}\text { Strain, strain } \\
\text { background } \\
\text { (M. } \\
\text { musculus) }\end{array}$ & Scx-GFP, C57BL/6 & $\begin{array}{l}\text { DOI: } 10.1002 / d v d y . \\
21179\end{array}$ & $\begin{array}{l}\text { RRID:MGI: } \\
3717422\end{array}$ & FACS \\
\hline $\begin{array}{l}\text { Strain, strain } \\
\text { background } \\
\text { (M. } \\
\text { musculus) }\end{array}$ & $\begin{array}{l}\text { Col2a1-Cre, C57BL/6 and B6.129 } \\
\text { (ICR) }\end{array}$ & PMID:10686612 & & $\begin{array}{l}\text { Used as mixed } \\
\text { background (C57BL/6 } \\
\text { and B6.129 (ICR)) for } \\
\text { LCM }\end{array}$ \\
\hline $\begin{array}{l}\text { Strain, strain } \\
\text { background } \\
\text { (M. } \\
\text { musculus) }\end{array}$ & $\begin{array}{l}\text { Col2-CreER }{ }^{T} \text {, } \\
\text { C57BL/6 and B6.129 (ICR) }\end{array}$ & $\begin{array}{l}\text { DOI: } 10.1002 / d v d y . \\
20892\end{array}$ & $\begin{array}{l}\text { RRID:IMSR_JAX: } \\
006774\end{array}$ & $\begin{array}{l}\text { Used as mixed } \\
\text { background (C57BL/6 } \\
\text { and B6.129 (ICR)) for } \\
\text { FACS }\end{array}$ \\
\hline $\begin{array}{l}\text { Strain, strain } \\
\text { background } \\
\text { ( } M \text {. } \\
\text { musculus) }\end{array}$ & Floxed Klf2, C57BL/6 & Eric Sebzda & & $\begin{array}{l}\text { DOl:10.1016/j.devcel. } \\
\text { 2006.09.006 }\end{array}$ \\
\hline $\begin{array}{l}\text { Strain, strain } \\
\text { background } \\
\text { (M. } \\
\text { musculus) }\end{array}$ & Floxed Klf4, C57BL/6 & MMRRC* & $\begin{array}{l}\text { RRID:MMRRC } \\
\text { 029877-MU }\end{array}$ & $\begin{array}{l}\text { PMID:12015290 } \\
\text { *Mutant Mouse } \\
\text { Regional Resource } \\
\text { Center at UC Davis }\end{array}$ \\
\hline $\begin{array}{l}\text { Strain, strain } \\
\text { background } \\
\text { ( } M \text {. } \\
\text { musculus) }\end{array}$ & Prx1-Cre, C57BL/6 & $\begin{array}{l}\text { DOI:10.1002/gene. } \\
10092\end{array}$ & & \\
\hline $\begin{array}{l}\text { Strain, strain } \\
\text { background } \\
\text { (M. } \\
\text { musculus) }\end{array}$ & C57BL/6 & $\begin{array}{l}\text { The Jackson } \\
\text { Laboratory }\end{array}$ & & $\begin{array}{l}\text { In situ hybridization } \\
\text { and single-molecule } \\
\text { fluorescent in situ } \\
\text { hybridization }\end{array}$ \\
\hline $\begin{array}{l}\text { Strain, strain } \\
\text { background } \\
\text { (M. } \\
\text { musculus) }\end{array}$ & $\begin{array}{l}\text { FVB/Shh-ZRSem7Axvi (396C>T } \\
\text { variant knock-in), FVB }\end{array}$ & $\begin{array}{l}\text { DOI:10.1016/j.cell. } \\
\text { 2020.02.031 }\end{array}$ & & $\begin{array}{l}\text { Enhancer reporter } \\
\text { assays in mouse } \\
\text { embryos }\end{array}$ \\
\hline $\begin{array}{l}\text { Strain, strain } \\
\text { background } \\
\text { (M. } \\
\text { musculus) }\end{array}$ & FVB & Charles River & $\begin{array}{l}\text { https://www. } \\
\text { criver.com/ }\end{array}$ & $\begin{array}{l}\text { Enhancer reporter } \\
\text { assays in mouse } \\
\text { embryos }\end{array}$ \\
\hline Antibody & anti-DIG-POD (sheep polyclonal) & Roche & $\begin{array}{l}\text { Cat\# } \\
11207733910\end{array}$ & $\begin{array}{l}\text { ISH (1:300), DOI:10. } \\
\text { 1007/978-1-62703- } \\
989-5 \_15\end{array}$ \\
\hline Antibody & anti-FITC-POD (sheep polyclonal) & Roche & $\begin{array}{l}\text { Cat\# } \\
11426346910\end{array}$ & $\begin{array}{l}\text { ISH }(1: 200) \\
\text { DOI:10.1007/978-1- } \\
62703-989-5 \_15\end{array}$ \\
\hline
\end{tabular}

Continued on next page 
Appendix 1-key resources table continued

\begin{tabular}{|c|c|c|c|c|}
\hline $\begin{array}{l}\text { Reagent } \\
\text { type } \\
\text { (species) or } \\
\text { resource }\end{array}$ & Designation & Source or reference & Identifiers & $\begin{array}{l}\text { Additional } \\
\text { information }\end{array}$ \\
\hline $\begin{array}{l}\text { Commercial } \\
\text { assay or kit }\end{array}$ & TSA Plus Fluorescent Systems Kit & Perkin Elmer & $\begin{array}{l}\text { Cat\# } \\
\text { NEL753001KT }\end{array}$ & $\begin{array}{l}\text { ISH (Cy3 + } \\
\text { fluorescein), } \\
\text { DOI:10.1007/978-1- } \\
62703-989-5 \_15\end{array}$ \\
\hline Antibody & Anti-SOX9 (rabbit polyclonal) & Millipore & AB5535 & $(1: 200)$ \\
\hline $\begin{array}{l}\text { Commercial } \\
\text { assay or kit }\end{array}$ & $\begin{array}{l}\text { Histogene LCM Frozen Section } \\
\text { Staining Kit }\end{array}$ & $\begin{array}{l}\text { ThermoFisher } \\
\text { Scientific }\end{array}$ & Cat\# KIT0401 & LCM \\
\hline $\begin{array}{l}\text { Commercial } \\
\text { assay or kit }\end{array}$ & MembraneSlide 1.0 PET & Carl Zeiss Microscopy & $\begin{array}{l}\text { Cat\# 415190- } \\
9051-000\end{array}$ & LCM \\
\hline $\begin{array}{l}\text { Commercial } \\
\text { assay or kit }\end{array}$ & AdhesiveCap 500 clear & Carl Zeiss Microscopy & $\begin{array}{l}\text { Cat\# 415190- } \\
9211-000\end{array}$ & LCM \\
\hline $\begin{array}{l}\text { Commercial } \\
\text { assay or kit }\end{array}$ & RNeasy FFPE Kit & Qiagen & Cat\# 73504 & LCM \\
\hline $\begin{array}{l}\text { Sequence- } \\
\text { based } \\
\text { reagent }\end{array}$ & smFISH probes & $\begin{array}{l}\text { Stellaris FISH Probe } \\
\text { Designer (Biosearch } \\
\text { Technologies, Inc, } \\
\text { Petaluma, CA) }\end{array}$ & & $\begin{array}{l}\text { See } \\
\text { Supplementary file } 2\end{array}$ \\
\hline $\begin{array}{l}\text { Software, } \\
\text { algorithm }\end{array}$ & $\begin{array}{l}\text { Pipeline Pilot-designed pipeline for } \\
\text { transSeq }\end{array}$ & INCPM & $\begin{array}{l}\text { https:// } \\
\text { incpmpm. } \\
\text { atlassian.net/ } \\
\text { wiki/spaces/ } \\
\text { PUB/pages/ } \\
\text { 36405284/ } \\
\text { tranSeq+on } \\
\text { +Pipeline-Pilot }\end{array}$ & Bulk RNA sequencing \\
\hline $\begin{array}{l}\text { Software, } \\
\text { algorithm }\end{array}$ & HTseq-count & $\begin{array}{l}\text { DOI: } 10.1093 / \\
\text { bioinformatics/btu638 }\end{array}$ & & \\
\hline $\begin{array}{l}\text { Software, } \\
\text { algorithm }\end{array}$ & DESeq2 & $\begin{array}{l}\text { DOI:10.1186/s13059- } \\
\text { 014-0550-8 }\end{array}$ & Version 1.4 .5 & \\
\hline $\begin{array}{l}\text { Software, } \\
\text { algorithm }\end{array}$ & Expander package & $\begin{array}{l}\text { DOI: } 10.1038 / \text { nprot. } \\
\text { 2009.230 }\end{array}$ & $\begin{array}{l}\text { Version 7.1, } \\
\text { CLICK algorithm }\end{array}$ & \\
\hline $\begin{array}{l}\text { Software, } \\
\text { algorithm }\end{array}$ & cellranger & 10x Genomics & Version 3.0.2 & $\begin{array}{l}\text { scRNA-seq } \\
\text { bioinformatic analysis }\end{array}$ \\
\hline $\begin{array}{l}\text { Software, } \\
\text { algorithm }\end{array}$ & DropletUtiles & $\begin{array}{l}\text { DOI:10.1186/s13059- } \\
\text { 019-1662-y }\end{array}$ & Version 1.6.1 & $\begin{array}{l}\text { scRNA-seq } \\
\text { bioinformatic analysis }\end{array}$ \\
\hline $\begin{array}{l}\text { Software, } \\
\text { algorithm }\end{array}$ & Seurat & DOI:10.1038/nbt.4096 & Version 3.1 .5 & $\begin{array}{l}\text { scRNA-seq } \\
\text { bioinformatic analysis }\end{array}$ \\
\hline Other & Bulk RNA sequencing dataset & This paper & $\begin{array}{l}\text { NCBI GEO } \\
\text { (GSE144306) }\end{array}$ & \\
\hline Other & $\begin{array}{l}\text { Single-cell RNA sequencing } \\
\text { dataset }\end{array}$ & This paper & $\begin{array}{l}\text { NCBI GEO } \\
\text { (GSE160090) }\end{array}$ & \\
\hline $\begin{array}{l}\text { Commercial } \\
\text { assay or kit }\end{array}$ & Hiseq 2500 SR50 cycles kit & Illumina & & Bulk RNA sequencing \\
\hline $\begin{array}{l}\text { Commercial } \\
\text { assay or kit }\end{array}$ & $\begin{array}{l}\text { 10x Genomics Chromium Single } \\
\text { Cell 3' Reagent Kit }\end{array}$ & 10x Genomics & & $\begin{array}{l}\text { User Guide v3/v3.1 } \\
\text { Chemistry }\end{array}$ \\
\hline $\begin{array}{l}\text { Commercial } \\
\text { assay or kit }\end{array}$ & $\begin{array}{l}\text { NEBNext Library Quant Kit for } \\
\text { Illumina }\end{array}$ & NEB & & \\
\hline $\begin{array}{l}\text { Commercial } \\
\text { assay or kit }\end{array}$ & SP 100 cycles reagent kit & Illumina & & \\
\hline Other & $\begin{array}{l}\text { Alexa Fluor } 488 \text { conjugated } \\
\text { phalloidin }\end{array}$ & $\begin{array}{l}\text { ThermoFisher } \\
\text { Scientific }\end{array}$ & A12379 & smFISH \\
\hline Other & ProLong Gold & Molecular Probes & P36934 & smFISH \\
\hline
\end{tabular}

Continued on next page 
Appendix 1-key resources table continued

\begin{tabular}{|c|c|c|c|c|}
\hline $\begin{array}{l}\text { Reagent } \\
\text { type } \\
\text { (species) or } \\
\text { resource }\end{array}$ & Designation & Source or reference & Identifiers & $\begin{array}{l}\text { Additional } \\
\text { information }\end{array}$ \\
\hline $\begin{array}{l}\text { Commercial } \\
\text { assay or kit }\end{array}$ & $\begin{array}{l}\text { NextSeq } 500 \text { High Output v2 Kit } \\
\text { (75 cycles) }\end{array}$ & Illumina & FC-404-2005 & \\
\hline $\begin{array}{l}\text { Commercial } \\
\text { assay or kit }\end{array}$ & Nextera Index Kit 24ind, 96smp & Illumina & FC-121-1011 & \\
\hline $\begin{array}{l}\text { Commercial } \\
\text { assay or kit }\end{array}$ & $\begin{array}{l}\text { Nextera DNA Sample Prep Kit (24 } \\
\text { sam) }\end{array}$ & Illumina & FC-121-1030 & \\
\hline $\begin{array}{l}\text { Software, } \\
\text { algorithm }\end{array}$ & Bowtie2 & $\begin{array}{l}\text { DOI:10.1186/s13040- } \\
\text { 014-0034-0 }\end{array}$ & Version 2.3.4.1 & \\
\hline $\begin{array}{l}\text { Software, } \\
\text { algorithm }\end{array}$ & Picard 'MarkDuplicates' & $\begin{array}{l}\text { http://broadinstitute. } \\
\text { github.io/picard/ }\end{array}$ & Version 1.119 & \\
\hline $\begin{array}{l}\text { Software, } \\
\text { algorithm }\end{array}$ & MACS2 & $\begin{array}{l}\text { DOI:10.1186/gb-2008- } \\
\text { 9-9-r137 }\end{array}$ & $\begin{array}{l}\text { Version } \\
2.1 .1 .20160309\end{array}$ & \\
\hline $\begin{array}{l}\text { Software, } \\
\text { algorithm }\end{array}$ & BEDtools & $\begin{array}{l}\text { DOI: } 10.1002 / \\
\text { 0471250953.bi1112s47 }\end{array}$ & Version 2.27 .1 & \\
\hline $\begin{array}{l}\text { Software, } \\
\text { algorithm }\end{array}$ & SAMtools & $\begin{array}{l}\text { DOI:10.1093/ } \\
\text { bioinformatics/btp352 }\end{array}$ & Version 1.19 & \\
\hline $\begin{array}{l}\text { Software, } \\
\text { algorithm }\end{array}$ & GREAT & DOI: 10.1038/nbt.1630 & Version 4.0.4 & \\
\hline $\begin{array}{l}\text { Software, } \\
\text { algorithm }\end{array}$ & HOMER & PMID:20513432 & Version 1.9 & \\
\hline $\begin{array}{l}\text { Software, } \\
\text { algorithm }\end{array}$ & Genomatix & & & \\
\hline Other & ATAC-seq dataset & This paper & $\begin{array}{l}\text { NCBI GEO } \\
\text { (GSE144306) }\end{array}$ & \\
\hline Other & $\begin{array}{l}\text { histone modification datasets } \\
\text { H3K27ac, H3K4me1, H3K4me3, } \\
\text { H3K9me3 }\end{array}$ & $\begin{array}{l}\text { ENCODE Consortium } \\
\text { and the ENCODE } \\
\text { production laboratory }\end{array}$ & $\begin{array}{l}\text { ENCSR905FFU } \\
\text { ENCSR426EZM } \\
\text { ENCSR416OYH } \\
\text { ENCSR022DED }\end{array}$ & ChIP-seq \\
\hline Other & phastConsElements60wayPlacental & $\begin{array}{l}\text { UCSC site; } \\
\text { Casper et al., } 2018\end{array}$ & & \\
\hline
\end{tabular}

